\title{
LA PRÉDICA DEL DIVERTIMENTO: LA FIGURACIÓN CARNAVALESCA DE JUDAS ISCARIOTE EN UNA SÁTIRA DE LUIS MARTÍN DE LA PLAZA
}

\author{
María Dolores Martos Pérez \\ Universidad DE MÁlaga \\ Afirmar que fue hombre y que fue incapaz de pecado encierra contradicción; \\ los argumentos de impeccabilitas y de humanitas no son compatibles. \\ J. L. Borges.
}

La «prédica» del género satírico y lo festivo de la poesía burlesca - entendiendo lo satírico y lo burlesco no como géneros delimitables por tal caracterización sino como conjuntos fluctuantes de un tipo único de código literario que, a partir del XVI, da entrada en la literatura a temas desterrados del discurso oficial por su escasa legitimidad $-{ }^{1}$ se aúnan en un texto del

\footnotetext{
${ }^{1}$ Se hace aquí necesaria una aclaración metodológica inicial. Para el propósito de este estudio no tiene utilidad el debate sobre los géneros, normalmente estéril, que aspira al establecimiento de límites entre la poesía satírica y burlesca, puesto que la realidad de los textos ha demostrado, en la mayor parte de los casos, que tales límites teóricos no tienen ninguna operatividad práctica. En una zona intermedia entre ambos polos (lo satírico y lo burlesco) han proliferado en la crítica toda
} 
antequerano Luis Martín de la Plaza (1577-1625), antologado por Espinosa en las Flores de poetas ilustres (1605).

Los objetivos que se pretenden en este acercamiento a la «Sátira a Judas Iscariote» de Luis Martín se centran en la redefinición de su papel en la antología en que se inserta - siempre desde la interacción texto (unidad)-conjunto en que se integra (antología) - y en su ubicación dentro de la producción poética de Luis Martín y del grupo antequerano. Para ello consideraremos dos ejes de análisis. Uno, horizontal, es decir, la «Sátira» en su «texto», o lo que es lo mismo, en la antología en que se integra; y, seguidamente, estudiaremos el texto en sí (lectura vertical): diseño retórico, posibles modelos, hipotextos o simples intertextualidades, así como la singularidad de la «Sátira».

Dos razones me han inducido a reproducir aquí la composición a cuyo estudio se dedican las siguientes páginas; la primera es la probable dificultad de acceso a ella; ${ }^{2}$ y, la segunda viene propiciada por el comentario a pie de verso que ocupará una parte amplia del análisis y que hace necesario acudir persistentemente a la base textual.

«Sátira a Judas Iscariote» ${ }^{3}$

Judas ladrón, ¿qué os provoca

a caminar tan apriesa,

que así con furia tan loca

os levantáis de la mesa

una serie de etiquetas como «satírico-burlesco», «jocoserio», «burlas y veras», etc. Sea cual sea el marbete que adoptemos, la única premisa de la que partimos es la ubicación de esta composición en ese arco flanqueado por lo satírico y su contenido moral y lo burlesco con su provocación a la risa. A pesar del título bajo el que aparece este texto de Luis Martín («sátira»), que, a priori, parece encuadrar genéricamente el texto, veremos inmediatamente que nos movemos en esta zona intermedia, entre las «veras» de la «prédica» y la risa del divertimento. No obstante, sirvan para encuadrar tal debate las siguientes aportaciones críticas fundamentales: el abarcador trabajo de Antonio Pérez Lasheras (1994); el análisis efectuado por Rodrigo Cacho Casal sobre el concepto de «sátira» desde los griegos hasta el siglo XVII (2004); la propuesta en torno a lo «jocoserio» de Jean-Pierre Entienvre (2004) y el capítulo de la monografía gongorina de Jesús Ponce Cárdenas sobre el concepto de lo «satírico» y «burlesco» en la poesía gongorina (2001, pp. 27-37).

${ }^{2}$ De las Flores de poetas ilustres, a falta todavía de la próxima aparición de una ya necesaria edición realizada por B. Molina Huete, sólo disponemos del facsímil de la edición vallisoletana de 1605 y de la obra completa de Luis Martín, reunida por J. M Morata Pérez (1995).

${ }^{3}$ Reproduzco el texto editado por Morata Pérez (1995, pp. 287-290). Véase también: Espinosa, Flores de poetas ilustres, 1991, f. 113r-114v. 
La prédica del divertimento: la figuración carnavalesca de Judas Iscariote en una sátira...

5

con el bocado en la boca?

¿Es porque estáis satisfecho

y no queréis más cenar?

no, mas antes yo sospecho

que lo vais a vomitar,

10

porque os entró en mal provecho.

Sentaos, mirad que es mancilla,

ya que os ha escogido Dios

por uno de su cuadrilla,

por ser mal jinete vos,

15

tan presto perdáis la silla.

Pero ya mi lengua calla;

¿quién me mete en avisaros?,

que, pues vos queréis dejalla,

después no habrá en que sentaros,

20

y os quedaréis de la agalla.

Y es bien, pues sois tan rüín,

que vuestra silla perdáis,

pues como villano, al fin,

por interés os trocáis

25

de apóstol en belleguín.

No ejecutéis tan mal trato, porque se conoce en vos,

al confirmar el contrato, que lleváis hurtado a Dios,

30 pues lo vendéis tan barato.

Mas sois picado y fullero, y en aqueso no advertís, ¡oh cuitado bordonero!, pues, cuando por Dios pedís,

$35 \quad$ os dan tan poco dinero.

Ciego os tiene la ambición que en vuestro pecho se cría, pues no veis, con la pasión, que cometéis simonía

40 y os condena a suspensión.

Si el dinero habéis jugado con sisones despenseros, 
pedidle a Pedro prestado; que él os prestará dineros, aunque empeñe su terciado.

Mas si el buen viejo repara y siente que sois aleve, tened por cosa muy clara que antes que Cristo cruz lleve la llevaréis por la cara.

Y aun quizá os irá con él tan mal, si a saber alcanza vuestra pretensión crüel, que no deje la venganza encomendada al cordel.

Que no podrán resistillo cuantos se pongan delante, para que con su cuchillo, primero que el gallo cante, no os corte a vos el gallillo.

Con vos enfadado estoy, porque en tal precio vendéis a quien yo el alma le doy, que aun en todo no tenéis para un juego del rentoy.

Y así, con justa razón a cólera me provoco de ver que en esta ocasión para dinero tan poco

$70 \quad$ lleváis tan grande bolsón.

Advertid que es desatino, pues sin blanca ha de volver; mas, a lo que yo imagino, del cuero queréis hacer unas botas de camino,

Porque es necedad pensar que la civil sinagoga de cuartos lo ha de colmar, porque no os dará una soga cuando os queráis ahorcar. 
La prédica del divertimento: la figuración carnavalesca de Judas Iscariote en una sátira...

Tomad el premio gentil que vuestra codicia espera; mas ¿qué le han de dar a un vil que le abolló la mollera al padre con un astil?

Quiero dejaros, cuitado; que debéis de estar corrido por la vaya que os he dado, pues, como quien ha perdido, 90 hacéis cara de ahorcado.

\section{La «SÁtira a Judas Iscariote» en Su MaCroteXto. Redefinición de la «SÁtira»}

en las seriaciones de las Flores de poetas ilustres de Pedro Espinosa

La poesía burlesca es mínimamente representativa en el corpus poético de Luis Martín de la Plaza. Sólo en tres composiciones ${ }^{4}$ acude al género burlesco, entre las que se encuentra la «Sátira a Judas Iscariote».

La historia textual de la «Sátira» se reduce a su inclusión en las Flores de poetas ilustres de Espinosa. Su publicación en la antología permite establecer el ante quem de la composición en noviembre de 1603, fecha de aprobación del florilegio. El cauce antológico por el que se ha transmitido y la singularidad que las Flores suponen para la revisión y reconsideración del género antológico, nos proveen de unas primeras pautas de lectura.

La «Sátira» resulta un texto «anómalo» por dos cuestiones: la disonancia de su asunto con la temática dominante en la poesía de Luis Martín y la consiguiente discordancia con los demás textos del mismo autor a los que Espinosa da cabida en su antología. Luis Martín es un poeta eminentemente lírico y es la poesía amorosa de factura petrarquista la más ampliamente recogida en las Flores y en el Cancionero Antequerano, así como la más representativa de su producción integral. Qué sentido tiene, pues, esta «Sátira» - en principio tan ajena a su quehacer poético - en el conjunto de su

\footnotetext{
${ }^{4}$ Las otras dos composiciones burlescas son de temática misógina: A una mujer flaca («Pluma menester habéis») y el romance de tema misógino «Aparte, la mi señora». Se alejan estos dos poemas de la «Sátira a Judas Iscariote» por la materia tratada, pues esta última se centra en la burla religiosa, mientras que en el plano formal la «Sátira» coincide en el uso de las quintillas con la composición $A$ una mujer flaca. También hay divergencia en la fuente textual puesto que la «Sátira» aparece en las Flores de poetas ilustres de 1605, mientras que las otras dos se recogen en el Cancionero Antequerano en el que la poesía de Luis Martín de la Plaza goza de amplia representación.
} 
poesía y por qué entre los veintinueve poemas ${ }^{5}$ seleccionados por Espinosa para conformar su antología se decanta por la «Sátira a Judas Iscariote», relegando, sin embargo, facetas más significativas del ejercicio literario de Luis Martín, como las composiciones de temática religiosa en su vertiente seria - con las que tanto éxito obtuvo en los certámenes - o los sonetos fúnebres y dedicatorios. A partir de los criterios de «novedad» y «variedad» en los que Espinosa basa su antología puede cobrar sentido tanto la inserción de la «Sátira» en las Flores como la ubicación secuencial que le adjudicó. Este análisis bidireccional, del texto seleccionado a la antología en que se inserta y de la antología al texto - de la unidad (microestructura o microtexto) al conjunto y del conjunto (macroestructura o macrotexto) a la unidad - nos permitirá, primero, establecer la singularidad del texto y, a continuación, la aportación de la «Sátira» a la antología como conjunto ordenado e intencionalmente organizado.

Acabamos de señalar que la «rareza» de la «Sátira» radica en su asunto burlesco-religioso frente a las preferencias temáticas de su autor, pero también su temática burlesca es una materia ajena a las que las antologías solían dar cabida. La poesía burlesca no había encontrado espacio en las colecciones y antologías impresas, dominadas hasta ahora por el asunto amoroso y donde el modelo del cancionero petrarquista seguía dictando los derroteros temáticos y estructurales de las compilaciones. ${ }^{6}$ A esta extrañeza de tipo genérico se suma su exigua difusión textual. A diferencia de muchas de las composiciones incluidas en las Flores de poetas ilustres no aparece con posterioridad en las otras antologías vinculadas al grupo antequerano-granadino: las Flores de Calderón de $1611^{7}$ y el Cancionero Antequerano fechado en $1627-28 .{ }^{8} Y$ en cuanto

\footnotetext{
${ }^{5}$ De los textos de Luis Martín de la Plaza contenidos en las Flores de poetas ilustres, veinticinco no ofrecen dudas de autoría, pero otros cuatro plantean problemas de atribución que no nos detenemos a examinar aquí. Remito para ello al estudio de Molina Huete, 2003, pp. 115-129.

${ }^{6}$ La poesía festiva, circunscrita a la circulación meramente manuscrita, empieza a llegar a la imprenta, incluida en este tipo de repertorios, a inicios del Barroco. Sirva como ejemplo de este cambio de la letra escrita a la impresa las Poesías varias de Alfay, donde las composiciones más abundantes son ya las festivas.

${ }^{7}$ Calderón, Flores de poetas, 1611, que se conserva en la Biblioteca de la Fundación Bartolomé March (Ms. 23/7/6. R-6673). Sólo contamos con la edición de Quirós de los Ríos y Rodríguez Marín de Segunda parte de las «Flores de poetas ilustres» ordenada por D. Juan Antonio Calderón, 1986.

${ }^{8}$ El manuscrito del Cancionero Antequerano se encuentra en Antequera [signatura 9816 M / 6 (I), (II), (III), (IV)]. En cuanto a ediciones, contamos con la fragmentaria realizada por Alonso (Cancionero Antequerano recogido por los años de 1627 y 1628 por Ignacio de Toledo y Godoy, 1950) y la publicación de los sonetos por Lara Garrido ([Cancionero Antequerano] I Variedad de sonetos, 1988).
} 
La prédica del divertimento: la figuración carnavalesca de Judas Iscariote en una sátira...

al tratamiento crítico, no ha sido mayor su fortuna. Se reduce, en lo que yo he podido conocer, a las notas de J. M. Morata Pérez en su edición ${ }^{9}$ y los apuntes de James O. Crosby al anotar los Sueños y Discursos de Quevedo. ${ }^{10}$

La valoración de las escasas y puntuales incursiones en el género satíricoburlesco por parte de Luis Martín de la Plaza y el intento de extraer posibles intencionalidades nos conduce al terreno de la simple especulación sin que en él florezca nada de sólido fundamento. Su pluma no se encontraba fácilmente con lo jocoso. Eligió dos temas para sus tres composiciones burlescas, el misógino y el burlesco-religioso y creo que, más allá de una finalidad moral, censora, se encuentra el mero juego de la escritura, del afán de explorar nuevos ámbitos, temáticos y formales, para la experimentación creativa.

Conjeturas más clarificadoras, sin embargo, puede aportar la publicación de la «Sátira» en las Flores de poetas ilustres de Pedro Espinosa. Los posibles argumentos que hoy podamos esgrimir acerca de las motivaciones que llevaron al antólogo a escoger la «Sátira» para formar su conjunto poético nos proporcionan el primer testimonio recepcional sobre los elementos de la «Sátira» que fueron para Espinosa representativos de esa vanguardia poética que codificó en su antología. Si Espinosa ofreció una poética - no teórica sino desde los textos, sirviéndose del vehículo de la antología - en el camino hacia la poesía cultista, qué justifica la inclusión de la «Sátira» de Luis Martín entre esos textos novedosos, avanzadillas de una nueva poesía.

Una hipótesis plausible acerca de las razones por las que Espinosa presentó una faceta tan poco expresiva del sentir poético general de Luis Martín ${ }^{11}$ es la que formula Belén Molina al proponer que la elección de esta composición de temática religiosa en su vertiente burlesca pudo estar motivada

\footnotetext{
${ }^{9}$ Martín de la Plaza, Poesías completas, pp. 287-290. La anotación de J. M. Morata Pérez se reduce a la intelección pero prescinde de cualquier nota interpretativa.

${ }^{10}$ Quevedo, Sueños y Discursos, 1993, vol. 2, pp. 990, 1245, 1248, 1252-1255 y 1162.

11 «De entrada se puede afirmar que el interés de Espinosa iba orientado hacia la vena lírica en los versos de arte mayor de Luis Martín. La mayoría en Flores son sonetos amorosos, así como la mayor parte de las canciones, en el mejor registro petrarquista [...] Ha descartado el antólogo todo el bloque religioso (y en nuestro autor [Luis Martín] es más que significativo, ya que no se duda de su perfección y valía al haber sido muy premiado en certámenes); también han sido eliminados el conjunto de sonetos fúnebres y dedicatorios [...]», Molina Huete, 2003, p. 121. La selección de este texto por Espinosa se aleja del conjunto general de la producción de Luis Martín tanto en el tema, burlesco-religioso, como en el molde formal - la «Sátira» está en octosílabos más profusamente empleada por Luis Martín, el endecasílabo.
} 
por la rivalidad del antólogo con Luis Martín, especialmente patente en textos de temática religiosa; de ahí que no seleccionara ningún texto serio de este asunto para su antología ${ }^{12}$ y sí, en cambio, uno de burlas. Este tipo de textos burlescos-religiosos eran muy comunes en la época pero apenas se conservan porque no pasaban a ser fijados por escrito.

Junto a estas razones extratextuales, la ubicación del texto de Luis Martín ocupa en la antología sitúa al lector en un camino de interpretación muy determinado. ${ }^{13}$ De la colocación de la «Sátira» en la antología podría deducirse, como explica la profesora Molina, «un intento de Pedro Espinosa de alinearlo con Quevedo». ${ }^{14}$ El texto de Luis Martín se integra en una serie de siete composiciones satíricas que van de la 119 a la 138. De ellas cuatro son de contenido clásico y dos de temas contemporáneos a los autores: la [127], una redondilla de Quevedo «A un Cristiano nuevo junto al altar de san Antón» ${ }^{15}$ y la [138], sátira en quintillas, dedicada a Judas por Luis Martín. ${ }^{16}$ Indiscutiblemente, los supuestos que maneja Belén Molina en esas propuestas de seriaciones son acertados, pero el estudio pormenorizado de cada texto - la «Sátira a Judas Iscariote» en este caso - dará nueva luz a la serie en que se integra y al conjunto general que Espinosa pudo idear.

Una lectura no demasiado profunda de las dos composiciones, la de Quevedo y la «Sátira» de Luis Martín, revela la gran distancia que media entre ambas. Más que un intento de alinear ${ }^{17}$ a Luis Martín con Quevedo, el propósito

\footnotetext{
${ }^{12}$ Molina Huete, 2003, pp. 121-122.

${ }^{13}$ Belén Molina en el estudio dedicado a las Flores de poetas ilustres ya citado ha demostrado cómo los poemas de la antología dialogan entre sí formando seriaciones poemáticas que constituyen guías de lectura ideadas por el poeta-antólogo en continuas llamadas de atención al lector atento.

${ }^{14}$ Molina Huete, 2003, p. 121.

${ }^{15}$ Reproduzco a continuación la breve composición de Quevedo A un cristiano nuevo junto al altar de san Antón (Espinosa, Flores de poetas ilustres, 1991, f. 101v.)

Aqui yace Mosén Diego,

a santo Antón tan vezino,

que huyendo de su cochino vino a parar en su fuego.

${ }^{16}$ La numeración de las composiciones y la propuesta de seriación es la que traza Molina Huete, 2003, p. 121.

${ }^{17}$ En esta misma línea nos sitúa el comentario de A. Alatorre al hablar de influencias en Luis Martín, sobre todo, de Góngora y Quevedo: «Donde sí está muy presente Quevedo es en los poemas 133 [«Pluma menester habéis] y 136 [«Judas ladrón, que os provoca»] (los únicos que Luis Martín hizo en quintillas)» (Alatorre, 1997, p.442).
} 
La prédica del divertimento: la figuración carnavalesca de Judas Iscariote en una sátira...

perece ser el contrario: si no oponerlo quizá sí ofrecerlo como dos maneras muy distintas de abordar la temática religioso-burlesca. No olvidemos que uno de los criterios de selección del antólogo era la «varia brevedad, pues esta trae la hermosura y el gusto». ${ }^{18} \mathrm{Si}$ bien la «Sátira a Judas Iscariote» comparte serie con Quevedo en las Flores, ambas composiciones difieren tanto estilística como estructuralmente. Comparten la invectiva contra los judíos - en Quevedo se hace patente en una serie de lexemas («cristiano nuevo», «monsén», «Diego» y «Cochino») y en el texto de Luis Martín se centra en las quintillas finales - pero la trabazón conceptual y la potencialidad alusiva de la palabra en Quevedo ${ }^{19}$ es magistralmente superior a dicho recurso en la pluma de Luis Martín. El conceptismo de esos cuatro versos quevedianos dista considerablemente del procedimiento alusivo y el tipo de juegos verbales, eminentemente manieristas y no todavía plenamente barrocos, con los que Luis Martín crea la comicidad. En el supuesto de la variedad, nada más útil que el contraste; contraste en cuanto a temas y, también, en lo que se refiere a las formas de cultivarlos. La redondilla quevediana y las quintillas de Luis Martín coinciden en el tema pero difieren en la ideación técnica. La crítica contra los judíos, desarrollada en las tres últimas quintillas, ponen en contacto la «Sátira» de Luis Martín y la redondilla quevediana, dedicada «a un cristiano nuevo», «mote aplicado a los judíos y moros convertidos al catolicismo». ${ }^{20}$ En Luis Martín la práctica manierista determina el diseño retórico, elocutivo y la dispositio, mientras que en Quevedo identificamos las marcas estilísticas del conceptismo sacro. Junto a la temática, el aspecto formal también alinea a Luis Martín con Quevedo. El autor de la «Sátira a Judas Iscariote» prefirió el cultivo del verso de arte mayor mientras que las tres composiciones burlescas le permitieron la incursión en el romance ${ }^{21}$ («Aparte, la mi señora») y la quintilla («Pluma menester habéis» y la «Sátira a Judas Iscariote»). Por tanto, similitud temática y estrófica, pero variación en el sentido, finalidad y realización artística de dos composiciones y de dos poetas que Espinosa agrupa en una microserie de las Flores.

\footnotetext{
18, Son palabras de Espinosa en el «Prólogo al lector», Flores de poetas ilustres, 1991.

${ }^{19}$ Para el comentario de las alusiones a los judíos véase la anotación de la redondilla de J. O. Crosby (Quevedo, Poesía varia, 1985, pp. 47-48).

${ }^{20}$ Quevedo, Poesía varia, 1985, p. 47.

${ }^{21}$ De temática amorosa son otros dos romances dedicados a Amarilis: CXXI, pp. 269-270 y CXXXII, 271-280 (Martín de la Plaza, Poesías completas, 1995).
} 
La ubicación y definición de la «Sátira a Judas Iscariote» de Luis Martín dentro de la vertiente satírico-burlesca que recorre las Flores es otra vía de indagación. Hay que considerar, primero, que la poesía satírico-burlesca en la antología antequerana no es de las facetas más cultivadas y que su funcionalidad esencial es la divergencia con las composiciones serias, con el fin de proporcionar al lector «descansos» frente a la gravedad de los textos serios. Si la temática religiosa en su vertiente solemne tiene en la antología "carácter contrarreformista», ${ }^{22}$ la vena humorístico-satírica, en contraste con ella, resta seriedad al asunto sacro, convirtiéndo el tema religioso en un ámbito temático más de experimentación literaria. Se recrea la «Sátira» en el solaz de la risa y el regocijo de lo liviano con algunas pinceladas de crítica antijudaica y burla de la avaricia.

Desde ese escaparate de poesía que es toda antología, las Flores de poetas ilustres pone a disposición del lector la gran variedad de sendas por las que discurre la nueva poesía, la vanguardia del barroco, recogiendo las diversas prácticas poéticas de principios del XVII que incluyen, tanto los textos impregnados de la estética manierista, como los que se apuntan ya manifiestamente al conceptismo barroco. Sirvan de ejemplo la «Sátira a Judas Iscariote» de Luis Martín y la redondilla de Quevedo.

\section{INSTANCIAS DisCURSIVAS EN LA CONFIGURACIÓN DE UNA FIGURA BURLESCA. ENTRE EL VEJAMEN Y LA CARNAVALIZACIÓN}

El referente en torno al cual se organiza el discurso satírico ideado por Luis Martín es el apóstol Judas Iscariote, ya identificado como tal en el título y en el primer verso - «Judas, ladrón...»-, cuyo retrato va a modelarse a través de un sujeto o voz lírica en primera persona

Este diseño retórico-discursivo hace operativo el concepto de «figura» ${ }^{23}$ como piedra angular del análisis. Se impone como primer asunto abordar es la tradición o basamento que arrastra una figura como la del apóstol Iscariote;

\footnotetext{
${ }^{22}$ Molina Huete, 2003, p. 267.

${ }^{23}$ Emplearemos el concepto de «figura» como acercamiento metodológico a la «Sátira a Judas Iscariote» de Luis Martín. Muy sugerente y útil al respecto es el análisis de este concepto en la obra de Quevedo por Schwartz Lerner, 1986. Igualmente, atenderemos al estudio de Lara Garrido (1995) acerca de la otra composición de Luis Martín en quintillas («Pluma menester habéis»), planteado «desde sus interferencias contextuales y cotextuales, o ascendencia y descendencia de una "figura" quevediana» (Lara Garrido, 1995, p. 414).
} 
La prédica del divertimento: la figuración carnavalesca de Judas Iscariote en una sátira...

qué material tan variado y de distintas procedencias - la tradición bíblica, la imaginación popular, las manifestaciones artísticas, las recreaciones literarias, ${ }^{24}$ etc. - puede revertir el poeta en un retrato satírico de Judas. Así pues, determinar las claves de la «resemantización ${ }^{25}$ a que Luis Martín somete tanto la «figura» - rasgos físicos y psicológicos - del apóstol díscolo como del discurso satírico que este ha propiciado es exigencia inexcusable para emprender la interpretación de la «Sátira». Ello equivale a establecer qué factores de la descripción de Judas resultan productivos en el discurso que Luis Martín ha trazado para generar el pretendido efecto satírico. La figura de Judas es apta para un tratamiento satírico en tanto en cuanto representa un defecto moral, ${ }^{26}$ esencialmente, la traición y la avaricia, las cuales, además,

\footnotetext{
${ }^{24}$ A ello hay que sumar la visión que un hombre del XVII podría tener de tal personaje, integrado en el acervo imaginístico popular, al menos, del mundo católico occidental.

${ }^{25}$ En el tratamiento de la figura de Judas en la lírica áurea es esencial la atención que a este personaje presta Quevedo, tanto en sus obras en prosa, sobre todo los Sueños (concretamente el Sueño del Infierno), como en verso. Por tanto, es exigencia sine qua non para el estudio de cualquier composición que atienda a este personaje la revisión de la obra quevediana y así lo haremos cuando sea pertinente. Ningún poeta del Siglo de Oro se interesó tanto por la figura de Judas como Quevedo. Lo menciona en treinta poemas (J. Vilar, 1978, pp. 106-119) pero sólo cuatro sonetos y un ovillejo lo tratan de manera exclusiva: los sonetos «¿Quién es el de las botas, que colgado», «"Tened a Cristo" son palabras vivas», «No, alma, no, ni la conciencia fíes», «Dícele a Judas el Pastor Cordero» y el ovillejo «Viendo el mísero Judas que vendido», números 540, 167, 168, 172 y 188 respectivamente de la edición de Blecua (Quevedo, Poesía original completa, 1999). El problema de la datación de las obras quevedianas dificulta el trazado de posibles conexiones intertextuales y el establecimiento de la pertinencia contextual de los textos de Quevedo respecto de la «Sátira» de Luis Martín. En todo caso, la atención a los textos quevedianos es esencial para la comprensión del tratamiento del personaje de Judas en la lírica del Siglo de Oro, puesto que la recreación quevediana alberga todos los elementos potenciales para posibles realizaciones satíricas o burlescas del apóstol traidor.

${ }^{26}$ Resulta significativo, pues, que Luis Martín no rentabilice la potencialidad burlesca de los rasgos físicos del apóstol - sobre todo la nariz y lo pelirrojo - , que tantas posibilidades ofrecía, por ejemplo, a Quevedo. En su recorrido por el Infierno, uno más de la galería de condenados a que pasa revista Quevedo es Judas, al que dedica los folios $47 \mathrm{v}-49 \mathrm{v}$. El autor de los Sueños recoge en esas páginas los rasgos configuradores esenciales del tipo. Lo incluye entre el grupo de los despenseros: «vereis [sic] en la parte del infierno màs honda a Judas con su familia descomulgada de Despenseros malditos» (Quevedo, Sueños y Discursos, 1993, vol. 1, p 177). Crosby insiste en la idea de Quevedo de tomar a los despenseros como herederos de Judas, motivo también presente en la «Sátira» de Luis Martín, en conexión con la avaricia del apóstol, la ambición y el tema del dinero. Además de pelirrojo, tres son los rasgos determinantes con los que Quevedo singulariza a Judas, y que rastreamos, después, en Luis Martín: la bolsa, el hecho de vender a Cristo con un beso y el ahorcamiento final, todos ellos consensados en estas dos líneas: «Y quièn sino vn Capon pudiera condenarse por lleuar las bolsas? Y quièn sino un Capon tubiera tan poca verguenza que vesara a Cristo para vendelle? Y quièn sino vn Capon tubiera tan poco animo que se aorcara [...] (Quevedo, Sueños y Discursos, 1993, vol. 1, p 178).
} 
hace extensible Luis Martín a un grupo social también rechazado y fuera de la norma social, los judíos. El género satírico, quizá por la mayor tensión del juego alusivo-elusivo, hace de los textos inscritos en él complejos signos del sistema cultural - en última instancia histórico - en que se insertan.

Por esto, una doble perspectiva se hace necesaria en el análisis: la del examen del artificio constructivo del discurso satírico, esto es, la descripción del ornatus; y la de la sátira como producto artístico dentro de la práctica literaria de principios del XVII y por una personalidad creadora como la de Luis Martín de la Plaza.

La descripción de una «figura» - que la retórica clásica encuadraba dentro del genus demostrativum - acarreaba el elogio, o bien el denuesto, lo que conllevaba un posicionamiento de la voz enunciativa respecto a la representación de que ésta es objeto. La óptica discursiva de la primera persona que Luis Martín de la Plaza ha escogido para su «Sátira a Judas Iscariote» imprime irremediablemente la subjetividad en la técnica descriptiva. ${ }^{27}$ La implicación del «yo discursivo» se hace efectiva por medio del tono admonitorio, que se sustenta en el apóstrofe continuo y sistemático a Judas desde el verso primero: «Judas ladrón, ¿Qué os provoca [...]?»; y que sigue con las formulaciones interrogativas de los versos 1-5, 6-7, 83-85. Asimismo, su participación se evidencia en el dictum asertivo - «yo sospecho» (v. 7), «yo imagino» (v. 73) - , junto a las distintas modulaciones que adopta el tono admonitorio en el desarrollo discursivo: de la aseveración atenuada - «yo sospecho» (v. 8), «yo imagino» (v. 74) - , al consejo condescendiente - « ¿quién me mete en avisaros?» (v.17), «advertid que es desatino» (v. 15) - , pasando por la advertencia - «tened por cosa muy clara» (v. 48) - y el dictado imperativo — «sentaos» (v. 3), «No ejecutéis» (v. 6), «pedidle» (v. 11), «tomad» (v. 17) —, hasta elevarse a la amenaza en los versos «Y aún quizá os irá con el / tan mal [...] / que no deje la venganza / encomendada al cordel» (v. 51-55) y culminar en la indignación y enojo final: «Con vos enfadado estoy» (v. 67), «a cólera me provoco» (v. 61). El grado de compromiso se sitúa en una escala ascendente en la que la implicación del «yo discursivo» con la figura que satiriza se va definiendo en un esquema contrapositivo que marca positivamente la actitud de esa primera persona frente a la caracterización burlesca del «tú» al que apela insistentemente.

\footnotetext{
${ }^{27}$ Schwartz Lerner, 1986, p. 252.
} 
La prédica del divertimento: la figuración carnavalesca de Judas Iscariote en una sátira...

En esta fijación del discurso satírico desde la primera persona y en las modulaciones de la actitud meramente intradiscursiva de ese sujeto lírico - aunque las implicaciones extratextuales también las podamos y debamos considerar - reside el sentido último del efecto satírico perseguido. Si bien el propósito de denostación de la figura de Judas es objetivo claro de la «Sátira» de Luis Martín, el posicionamiento de la voz enunicativa, más que hacia la censura, oscila a la condescendencia. Pero la condescendencia, entiéndase bien, no hacia Judas, traidor y verdugo de Cristo, en última instancia, referente de la figura que Luis Martín va conformando. No podía serlo en el espacio textual definido por el yo lírico, un espacio de contraposición y diferenciación de la primera persona y la figura que se va conformando. La permisión solo existe hacia la figura burlesca y ridícula que ha nacido del el universo textual de la «Sátira». El referente bíblico sirve de base para una reformulación del «tipo». La recreación llevada a cabo por Luis Martín se deriva - a la vez que se suma - de esa cadena, no sólo de textos escritos sino de la imagen que el folclore popular había creado. Junto a versiones ortodoxas existían otras prefiguraciones del apóstol, nacidas de fuentes más heterodoxas: desde la base de la figura bíblica se ha ido superponiendo toda una imaginería posterior que procede de los evangelios apócrifos, los relatos forjados por la imaginación popular, las procesiones de Semana Santa ${ }^{28}$ tan importantes en Andalucía, etc.

\footnotetext{
${ }^{28}$ El arraigo de las procesiones de Semana Santa en Andalucía se ha mantenido hasta la actualidad. Del mismo modo, en el siglo XVII, en provincias como Sevilla no había pueblo ni aldea que no albergase en sus calles pasos de imágenes bíblicas que alimentaban el fervor popular. Los elementos que inspiraban estos pasos provenían tanto de los dos Testamentos como de los Evangelios Apócrifos, el Catecismo, etc. (Caro Baroja, 1988, p. 56). A muchos de estos pasos acompañaban «figuras», esto es, actores que representaban - subrayemos esta palabra personajes bíblicos que personalizaban el pecado en cualquiera de sus manifestaciones. Estas representaciones eran de tipo carnavalesco y potenciaban en las figuras lo grotesco y caricaturesco. Resultan paradigmáticas las procesiones en Puente Genil, recogidas de forma meramente documental por Caro Baroja a mediados del pasado siglo XX. La figura de Judas acompaña a distintos pasos durante el miércoles, jueves y viernes, recreando los episodios más emblemáticos de la Pasión de Cristo en los que Judas intervino. El miércoles, al paso llamado de Nuestro Señor de la Humildad y la Paciencia, acompaña detrás "“La gente chusma", es decir, unos romanos de desecho con Judas. Estos personajes aluden también al prendimiento: van de aquí para allá interfiriéndose, pero más normalmente junto al paso, al son de un tambor. Son siete, cinco con escudos y alabardas y uno con bandera roja. Detrás de ellos marcha Judas con un "rostrillo" de barba rojiza, un traje en gran parte de color verde, y con la bolsa, símbolo de su traición en la mano. A Judas le siguen los chicos armando bulla» (Caro Baroja, 1988, p. 68). Está urdiendo aquí Judas la traición que desembocará en la muerte de Cristo. El siguiente día, el jueves, la figura de Judas se torna más trágica: lleva ahora el pelo negro y enmarañado y en la cara una expresión
} 
La superioridad moral de esa voz enunciativa queda evidenciada en el tono de consejo y en la actitud entre burlas y veras hacia la figura que satiriza y con la que en la estrofa de cierre acaba solidarizándose por la denigración cómica a que su discurso la ha sometido: «Quiero dejaros, cuitado; / que debéis de estar corrido / por la vaya ${ }^{29}$ que os he dado».

Un tipo de textos que se incluyen bajo el marbete de «vejámenes» ${ }^{30}$ puede clarificar o ayudar a redefinir la «rareza» de este texto de Luis Martín en la antología de Espinosa y en el conjunto de su producción literaria. Esta surtido de composiciones que pretenden dar 'burla, mofa o vaya' a Judas se destinaban, en su mayor parte, bien a justas o certámenes, bien a fiestas eclesiásticas con la finalidad de un entretenimiento piadoso y aleccionador. Tanto el diseño retórico-discursivo como la definición del discurso satírico como "vaya» cobran pleno sentido si se considera este arquetipo de vejámenes.

El diseño retórico-discursivo de la «Sátira de Judas Isaciote», que incide directamenteen el sentido dela invectiva, la entronca conestos textos quecircularon en su mayor parte manuscritos. Este tipo de composiciones de vejamen a Judas ${ }^{31}$ suelen aparecer junto a otras dedicadas al ciclo de la Pasión, o bien como textos para certámenes y justas ligadas al Santísimo Sacramento, y, también, como juegos dialéctico-literarios enmarcados en un contexto de entretenimiento eclesiástico. ${ }^{32}$

En las justas impresas del XVII apenas se recogen textos de vejámenes a Judas. ${ }^{33}$ La mayor parte de los conservados se encuentran manuscritos, modo de difusión que responde a la circunstancialidad con la que nacen.

\footnotetext{
de terror. Lo acompaña san Pedro, de rostro venerable, llevando un gallo o pollo blanco (Caro Baroja, 1988, p. 70). El viernes, una soga al cuello sujeta a una rama de higuera que lleva en la mano recuerda el suicidio (Caro Baroja, 1988, p. 78). Es razonadamente factible que Luis Martín conociera estas figuras que pululaban por las procesiones de Semana Santa, a manera de carnaval sacralizado, en un rito de representación que contenía en sí la subversiva semilla de la risa.

29 'Burla o mofa que se hace de alguno o chasco que se le da' (Diccionario de Autoridades).

${ }^{30}$ Estas composicones no han recibido mucha atención por parte de los estudiosos de la literatura y la bibliografía que podemos aducir es escasa. Un libro fundamental es el de G. Cara, Il «vejamen» in Spagna: juicio y regocijo letterario nella prima metà del XVII saecolo, Roma, Bulzoni, 2001.

${ }^{31}$ Agradezco a Inmaculada Osuna la generosidad con la que me ha proporcionado gran parte de los materiales sobre composiciones de vejamen que recojo en estas páginas.

${ }^{32}$ No pretendo dar un catálogo amplio ni exhaustivo de textos de vejamen a Judas sino sólo algunos que resulten indicativos y explicativos para la conformación de la «Sátira» de Luis Martín.

${ }^{33}$ Una de estas justas impresas recoje un certamen que tiene el siguiente asunto: «También merece Judas, que le pongan como merece. Él ha de entrar en este Certamen, como Ladrón, y como borrico, porque ay borrico, y Ladrón en la Historia. Él buelve el dinero de la venta (que dinero de venta, es hazienda del Diablo) y estotro Ladrón buelve el borrico (que hazienda de asnos, nunca luze, ni
} 
La prédica del divertimento: la figuración carnavalesca de Judas Iscariote en una sátira...

La circunstancia de que muchas de ellas están ligadas al Santísimo Sacramento puede explicar las alusiones en este tipo de textos a la Sagrada Cena, incidiendo en dos aspectos: la comida y el momento en que Judas se levanta de la mesa, al ser descubierto por Jesús. Así sucede con las endechas de A. de Ledesma - «Discipulo ingrato, / apóstol aleue, alça de la mesa, / no comas con gentes» — ${ }^{34}$, que comparten con el texto de Luis Martín la apelación insistente a la segunda persona, Judas. Sin embargo, frente a la composición del antequerano, marcada por la condescendencia del sujeto lírico hacia Judas - o al menos una buscada ambigüedad - Ledesma coloca un estribillo reiterado - «Mal prouecho te haga, / con ellos rebientes» - que particulariza en la virulencia de la invectiva. Caso semejante lo constituye la Troba a Iudas, «Y quien me la lleua?, la lleua, la lleua?...». ${ }^{35} \mathrm{La}$ apelación a Judas se efectúa en tercera persona, y el motivo central es el ahorcamiento, pero los versos iniciales, que aluden a la cena y al juego, ofrecen paralelismos significativos con el texto del poeta de Antequera:

parece). Aquél se ahorca por su gusto; y éste, contra toda su voluntad amanece aspado de aturdido a la puerta de San Juan de Dios, harto de andar toda la noche (que en esso para quien se dexa llevar de bestias). Quitóle el Santo el burro, apeándose primero el Ladrón de su asno; y dióle por él muy buenos consejos, y algunas reprehensiones. El que con más gracia, en veinte Quintillas muy jocosas, pintare este caso, será premiado como Dios fuere servido, y de más a más, llevará el mejor: por premio [...]». Está impreso en Sarabia, Justa literaria, certamen poético, o sagrado influxo, en la solemne, qvanto deseada Canonización del Pasmo de la Caridad, el Glorioso Patriarca y Padre de Pobres San Juand e Dios, Fundador de la Religión de la Hospitalidad. Celebróse en el claustro del Convento Hospital de Nuestra Señora del Amor de Dios, y Venerable Padre Antón Martín de esta Corte, el Domingo diez de junio del Año de mil seiscientos y noventa y vno, Madrid, Bernardo de Villa-Diego, 1692, fol. 314r, R/15239 y 7/107913 BNM.

${ }^{34}$ "Al santissimo Sacramento, y a la venta de Iudas. En metáfora de agua de manos. Endechas», en Ledesma, Tercera parte de Conceptos Espirituales. Con las obras hechas a la Beatificación del glorioso Patriarca Ignacio de Loyola, fundador de la Compañía de Iesus, para el Colegio de la ciudad de Segouia, 1612, fol 23r, R-16027 BNM.

${ }^{35}$ Incluida en Cantero Jiménez, Plavsibles elogios, célebre octava, circvlo festivo, corona que labraron, laureola que entretexieron, y victimas que sacrificaron, Sagradamente ambiciosos, En Aras de su piadoso çelo, los deuotos hijos del nunca bastantemente venerado San Felipe Neri. En sv Congregacion y nvevo Oratorio de la Nobilissima Ciudad del Valle de Vlid. A los veynte de Octubre de 1658, fols. 101-103. Esta composición se integra en una serie de textos en honor de san Felipe Neri, escritas por miembros de su congregación. Se agrupan por días y en el viernes se incluye esta troba: «Hizo la musica dmirable compañía hasta el fin, mas a el alçar se pusieron muy de re mi fa sol a cantar esta troba a Iudas, que es la Tarasca del dia del Corpus [...]» (fols. 100v-101r). Se enmarcan, pues, este tipo de composiciones en los momentos de solaz de los miembros de la comunidad eclesiástica. Esta faceta de entretenimiento o divertimento eclesiástico se observa también, por ejemplo, en la inclusión de una composición titulada El Juego de A Fray Juan de las cadenetas. A los efectos del Sacramento de la Eucaristía, y venta de Iudas, «Despues que el Rey de la gloria...» en una obra titulada Ivegos de Noche Bvena moralizados a la vida de Christo, martirio de Santos, y reformación de costumbres. Con vnas enigmas hechas para honesta recreación, Madrid, 1611, G-11155, British Museum, Londres, fols. 32r-34v. 
De un exceso mal dispuesto se sintió, que en cierta cena comiendo hasta rebentar, se fue a otra parte hazer venta.

Dizen que por cumplimiento, tomó un bocado en la mesa, no comió el bien porque luego se conoció su flaqueza.

Xugó al hombre, y diole mal, y arrojando moneda viendo lo que auía perdido se ahorca, y se desespera.

(vv. 13-24)

Muchos otros textos de vejamen a Judas reiteran el mismo esquema discursivo que Luis Martín plasma en su «Sátira». Pero no sólo en el diseño retórico-elocutivo (lo más común es la apelación en segunda persona pero también es frecuente referirse a Judas desde la tercera persona gramatical) rastreamos similitudes con el texto de Luis Martín sino también en los episodios escogidos - nos referimos, sobre todo, a la Sagrada Cena - así como en el vocabulario empleado, en el tipo de estrofa - que suele ser la quintilla, la redondilla o el romance-, en los mismos títulos con que se rotulan las composiciones — normalmente el de «sátira» o «vexamen» - en la mención del nombre de Judas en el primer verso ${ }^{36}$ etc. Por ejemplo, en el Vexamen a Ivdas Coplas, "A Iudas Bexamen doi...», ${ }^{37}$ la copla quince, recuerda el momento en que Judas se levanta de mesa con el mismo sintagma que Luis

\footnotetext{
${ }^{36}$ Pueden consultarse, al mismo respecto, las siguientes composiciones: El autor a Judas. «Falso Iudas no conuiene / oluidar lo que heziste» (Montemayor, La passion de Christo, compuesta en metro español, fols. 100r-100v); la composición de D. Agustín de Palacios, «A Iudas vejamen oy / Dar quiero determinado", (Martínez De Grimaldo, Fundacion, y fiestas de la Congregacion de los indignos esclavos del SS. Sacramento, que esta en el religioso convento de Santa Maria Magdalena, de la orden de S. Agvstin de esta Corte. Celebradas en los primeros cinquenta años de sv edad felice. Madrid, Diego Díaz de la Carrera, 1657, 3/62584 BNM, fol. 155v); Quintillas a Judas, «Judas para ser colgado...», en Tonos a lo Diuino y a lo Humano recogidos por el Licenciado D. Gerónimo Nieto Madaleno... y escriptos por el Maestro Manuel López Palacios..., Ms. de la Biblioteca Pública de Toledo, descrito por Esteve Barba, Catálogo de la Colección de manuscritos de la Biblioteca Borbón Lorenzana, Madrid, 1942, n 391 , fols. 26-27; un romance de Ovando y Santarén (Ocios de Castalia en diversos poemas, 1987, pp. 216219), presentado a un certamen en Úbeda e incluido en su obra más lograda Ocios de Castalia en diversos poemas... publicada en 1663.

${ }^{37}$ Poesias varias de grandes ingenios españoles. Recogidas por Ioseph Alfay, R-6797 BNM, pp. 48-49.
} 
La prédica del divertimento: la figuración carnavalesca de Judas Iscariote en una sátira...

Martín: «La embidia que le prouoca / le ha dado con grande priessa / que ahorcarse fue de la mesa / con el bocado en la boca». Los ecos con la primera quintilla de Luis Martín resuenan ya en una epidérmica lectura:

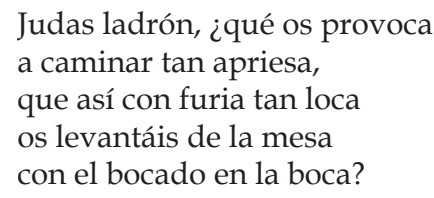

Por ejemplo, la Sátira a Ivdas Redondillas, "Ya Iudas llegado se ha», insiste - como el v. 30 de Luis Martín «pues lo vendéis tan barato»- en la venta realizada por apóstol: «que bien se vio ser hurtado / pues lo distes tan barato». ${ }^{39}$

Un último grupo de composiciones que nos detenemos a examinar se encuadran en el «octavo assunto» ${ }^{40}$ de una serie de cuestiones referidas a la capellanía de san Andres. Incluye este asunto una serie de alegatos que los poetas profieren para presentar su candidatura a una de las doces capellanías (en honor de los doce apóstoles) que tenía la Capilla de san Andrés y que queda vacante al morir el Patrón. Los alegatos tienen que ser ideados «de parte de Iudas, o por si mismo, en pretensión de esta Capellania, esforçándole con las razones con las razones que le dictare su ingenio» ${ }^{41} \mathrm{El}$ tercero, autoría del licenciado Bartolomé Gallego Sandoval, presenta varias semajanzas con el texto de Luis Martín. En primer lugar, emplea el dicho «quedarse en las agallas» que utiliza Luis Martín en el verso 20: «el que se ve en apreturas / por algunas trabesuras / se ha quedado en las agallas». ${ }^{42}$ Un poco más adelante se sirve del chiste dilógico en torno a la palabra «suspensión»:43 «y vive como en un sueño / en notable suspensión»." Y refiriéndose al prendimiento llama «cuadrilla» a los que apresarán a Cristo: «mas no entrará su quadrilla / hasta que el haga la seña». ${ }^{45}$ Otro alegato, el de

\footnotetext{
${ }^{38}$ Ledesma, Conceptos espirituales, 1602, R-985 BNM, composición 213, pp. 445-52.

${ }^{39}$ Ledesma, Conceptos espirituales, p. 450.

${ }^{40}$ Ávila, Epinicio sagrado..., Salamanca, 1687. Véase la segunda parte titulada «Epinicio. Cántico victorial al sumo Iove vencedor de Saturno. Canta Apolo», 2-10720 BNM, pp. 432-451.

${ }^{41}$ Ávila, Epinicio sagrado..., p. 434.

42 Ávila, Epinicio sagrado..., p. 438.

${ }^{43}$ Fray Diego de Ares Escrito escribe su alegato en quintillas y emplea la misma dilogía: «porque el mejor beneficio / tiene también suspensiones» (Âvila, Epinicio sagrado..., p. 444).

${ }^{44}$ Ávila, Epinicio sagrado..., p. 439.

${ }^{45}$ Ávila, Epinicio sagrado..., p. 439.
} 
Francisco Suárez de Medina se refiere, al igual que Luis Martín, a la avaricia de los judíos: «Y el darlo barato, fue / por ser gente tan mezquina, / que si les pido un real más / la venta se desperdicia». ${ }^{46} \mathrm{El}$ alegato undécimo, realizado por José de Oviedo emplea un juego paronomásico con la palabra «vaya»: "para que a Judas le vaya / vaya dando. ${ }^{47}$

Este tipo de composiciones de vejámenes a Judas le sirve a Luis Martín como esquema estructurador de su «Sátira», pero potencia el antequerano otros elementos que dan singularidad a su texto, principalmente dos: la figuración carnavalesca y la prédica antijudaica.

\section{LOS RESORTES DE LA COMICIDAD EN LA «SÁTIRA A JUDAS ISCARIOTE»: LA CONFORMACIÓN} DE UN UNIVERSO TEXTUAL DE LO BURLESCO

La base estructural de la «Sátira» se sustenta en un fictivo marco dialogal fundado en el apóstrofe sistemático a Judas por parte de ese sujeto poético que se implica en los trazos que van delineando de la vida del apóstol. Este diseño dialógico permite atraer la figura de Judas hacia la contemporaneidad de Luis Martín para que el «yo discursivo» construya, desde su mundo y mediante su propia observación, la imagen satírica del discípulo traidor. La concretización de la figura ${ }^{48}$ en el universo áureo es el núcleo del impulso satírico, y en la ambigua actitud del sujeto poético reside otro anclaje esencial de la comicidad del texto, todo ello apoyado en la contraposición temporal entre el contexto bíblico que funciona como referente, al menos en la mente del lector, y una atmósfera social de principios del XVII.

El inframundo áureo se introduce por los calificativos de «picado y fullero» (v. 31) y «bordonero» (v. 33) y con la transmutación de uno de los

\footnotetext{
${ }^{46}$ Ávila, Epinicio sagrado..., p. 443.

${ }^{47}$ Ávila, Epinicio sagrado..., p. 450.

${ }^{48}$ La pregunta que surge irremediablemente es cómo observaría un hombre del siglo XVII, el sujeto discursivo como ejemplo, la figura de Judas. La imagen de Judas como el gran traidor no tiene cabida en la mentalidad de un hombre del XVII en la que el valor del dinero acaba por sustituir cualquier otro principio (recuérdese, por ejemplo, el Don Dinero de Quevedo). Las licencias facilitadas por el ámbito de escritura al que se adscribe lo satírico-burlesco permite a Luis Martín insistir de forma continuada en el «mal trato» de Judas, priorizando su escasa habilidad mercantil frente a la falta moral de la traición. En una mentalidad medieval - por ejemplo, la de Dante al colocar a Judas junto a Bruto y Casio en su Infierno como emblemas de la traición - donde la lealtad ocupaba un lugar primordial en la escala de valores no posibilitaría una reescritura de Judas como la que propone Luis Martín.
} 
La prédica del divertimento: la figuración carnavalesca de Judas Iscariote en una sátira...

discípulos más fieles y el ministro más venerable de la Iglesia católica, san Pedro, ${ }^{49}$ en la figura de un bravucón.

El otro resorte básico de la comicidad estriba en la ambigua actitud del sujeto emisor. Si bien la correspondencia «yo discursivo»-«yo biográfico» no es pertinente en muchos casos, sí es un factor que se ha de tener en consideración en muchos otros. En el caso de Luis Martín no conocemos el marco pragmático de la «Sátira»: pudo ser compuesta para un certamen, para una reunión de amigos después de una de esas jornadas de Semana Santa en que el baile y la risa llenaban las calles, etc. Las posibilidades son diversas y no disponemos de ningún dato que haga primar una u otra. A ello hay que añadir que Luis Martín, como clérigo, ${ }^{50}$ se erige en portavoz de los valores eclesiásticos. El mundo de la Iglesia está presente en la «Sátira», tanto en el antijudaísmo como en los chistes vinculados a ese universo religioso.

No obstante, hay que verificar si, realmente, en el espacio textual la contraposición entre las dos figuras básicas del texto, un Judas a la manera de los pícaros del XVII y un «yo cristológico», es tan antitética como, en principio, puede parecer. ${ }^{51}$ Los argumentos que se esgrimen para censurar la conducta del apóstol se revelan absurdos, poniendo de relieve la inconsistencia de la argumentación que los sustenta. La oposición entre las dos instancias textuales se verbaliza por medio de la presencia de pronombres y adjetivos personales y posesivos, así como en formas verbales en primera y segunda persona:

\footnotetext{
${ }^{49}$ Tradicionalmente se ha destacado del apóstol la intensa admiración que profesaba a Cristo y el empeño que, por ello, tuvo en averiguar quién era el discípulo traidor de Cristo. San Agustín comenta que Cristo no le quiso revelar a san Pedro el nombre de Judas por temor a que matase al traidor. «El Crisóstomo es de la misma opinión, puesto que a propósito de esto dice: Si Pedro hubiese oído pronunciar el nombre del desgraciado felón, inmediatamente se habría levantado de su asiento para arrojarse sobre el traidor y despedazarle allí mismo, en presencia de todos» (De la Vorágine, 1982, vol. 1, p. 346-347). Quizá aquí pueda estar el germen de la hiperbolización de Luis Martín.

${ }^{50}$ Pocos datos conocemos sobre su vida excepto que «en febrero de 1598 era capellán de la Iglesia y monasterio de Santa María de Jesús (fundación de su madre) y ese mismo año recibe el presbiterado. Desde 1605 hasta 1622 al menos, es cura de la Iglesia de Santa María la Mayor» (Martín de la Plaza, Poesías completas, pp. 21-22).

${ }^{51}$ Mazzocchi (2001, p. 115) señala la contraposición entre la primera y segunda persona como característica de la lírica religiosa.
} 


\begin{tabular}{|c|c|c|c|}
\hline \multicolumn{2}{|c|}{$\begin{array}{l}\text { PRONOMBRES Y ADJETIVOS } \\
\text { (PERSONALES Y POSESIVOS) }\end{array}$} & \multicolumn{2}{|c|}{ FORMAS VERBALES } \\
\hline $\begin{array}{l}\text { Primera persona } \\
\text { («yo discursivo») }\end{array}$ & $\begin{array}{l}\text { Segunda persona } \\
\text { (Judas) }\end{array}$ & $\begin{array}{l}\text { Primera persona } \\
\text { («yo discursivo») }\end{array}$ & $\begin{array}{l}\text { Segunda persona } \\
\text { (Judas) }\end{array}$ \\
\hline $\begin{array}{l}\text { «yo» }(v v .8,63,73) \\
\text { «mi» (vv. 16) } \\
\text { «me» (vv. 17, 67) }\end{array}$ & 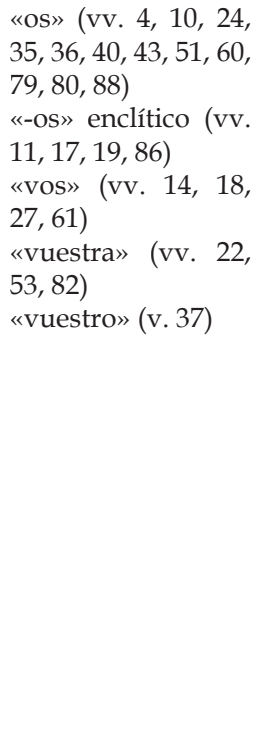 & $\begin{array}{l}\text { «sospecho» (v. 8) } \\
\text { «estoy» (v. 61) } \\
\text { «doy» (v. 63) } \\
\text { «provoco» (v. 67) } \\
\text { «imagino» (v. 73) } \\
\text { «quiero» (v. 86) } \\
\text { «he dado» (v. 88) }\end{array}$ & $\begin{array}{l}\text { «levantáis» (v. 4) } \\
\text { «estáis» (v. 6) } \\
\text { «queréis» (vv. 7, 18, 74) } \\
\text { «vais» (v. 9) } \\
\text { «perdáis» (v. 15) } \\
\text { «quedaréis» (v. 20) } \\
\text { «sois» (vv. 21, 31, 47) } \\
\text { «perdáis» (v. 22) } \\
\text { «trocáis» (v. 24) } \\
\text { «ejecutéis» (v.26) } \\
\text { «leváis» (vv. 29, 70) } \\
\text { «vendéis» (v. 30) } \\
\text { «advertís» (v. 32) } \\
\text { «pedís» (v. 34) } \\
\text { «veis» (v. 38) } \\
\text { «cometéis» (v. 39) } \\
\text { «habéis» (v. 41) } \\
\text { «llevaréis» (v. 50) } \\
\text { «tenéis» (v. 64) } \\
\text { «queráis» (v. 80) } \\
\text { «debéis» (v. 87) } \\
\text { «hacéis» (v.90) }\end{array}$ \\
\hline
\end{tabular}

Lógicamente, tienen mayor protagonismo cuantitativo las formas de segunda persona, puesto que la figura satirizada es el núcleo principal de la composición. Pero, sin embargo, la confrontación entre las instancias discursivas representa, en sí misma, un indicio de la funcionalidad de tal oposición. Su cometido es el de disociar las actitudes del productor del discurso frente a las del destinatario, cargando las primeras de un signo positivo en oposición a las del segundo. La alusión a una tercera persona, san Pedro, se proyecta hacia el reforzamiento de la actitud del sujeto poético: 
La prédica del divertimento: la figuración carnavalesca de Judas Iscariote en una sátira...

\begin{tabular}{|l|l|}
\hline $\begin{array}{c}\text { Pronombres y adjetivos } \\
\text { (personales y posesivos) }\end{array}$ & \multicolumn{1}{|c|}{ Formas verbales } \\
\hline «él» (vv. 44, 51) & «prestará» (v. 44) \\
«su» (vv. 45, 58) & «empeñe» (v. 45) \\
& «repara» (v. 46) \\
& «siente» (v. 47) \\
& «alcanza» (v. 52) \\
& «deje» (v. 54) \\
& «corte» (v. 60) \\
\hline
\end{tabular}

Otro factor de fundamental incidencia en la dinámica satírica es el molde estrófico elegido por Luis Martín, la quintilla ${ }^{52}$, como hemos visto, estrofa habitual en los textos de vejamen a Judas. La materia se ve constreñida en extensión e intensidad al tratarse de un metro reducido que no facilita la amplitud ni extensión. Lo más frecuente es que cada quintilla presente una agudeza dominante que «determina un equívoco en el verso de cierre». ${ }^{53}$ Así ocurre en las estrofas cinco, seis, siete y ocho, donde desarrolla una agudeza en cada una, que se resuelve en los dos versos finales o en el último. Además, obsérvese que todas las quintillas excepto la décimo quinta

\footnotetext{
${ }^{52}$ Los cauces formales más transitados por la poesía burlesca del XVI fueron el soneto y los tercetos, y en el XV el romance, ésta última forma elegida por Luis Martín para «Aparte, la mi señora». En cambio, se sirve Luis Martín de la quintilla en sus otras dos composiciones satíricas: «Pluma menester habéis» y la «Sátira» que nos ocupa. Es la quintilla un tipo de estrofa poco habitual en el inicio del XVII que se compone de cinco versos octosílabos y que Luis Martín hace rimar de la siguiente manera ABABADC. Clarke (1933, pp. 28-295) señala que se trata de una forma ligada a la redondilla, pues la encontramos unida a esta estrofa en sus orígenes. Es un tipo de estrofa genuinamente castellana que raramente se da en otros países y su uso se empieza a generalizar a principios del XVII. Expone Lara Garrido que, a partir de 1600, este tipo de estrofa queda circunscrita al ámbito de las burlas al considerarla un metro humilde y poco útil para otros propósitos, y sostiene que «tal mutación estuvo justamente sustentada en la propia práctica quevediana, ya que el autor e los Sueños las había empleado hacia la fecha citada [1600] en composiciones "ingeniosas y ligeras", "obras jocosas hechas para puro regocijo"» (1995, p. 437). Quevedo usa la quintilla en cuatro composiciones burlescas de mayor extensión: «Sola esta fiesta en mi vida», «Todo mi discurso atajo», y dos más breves «De Osuna y Aracïel», y «Moisés, rico mesonero» (675, 676, 813, 814, según la numeración de Blecua, 1999). Además de las concomitancias temáticas comentadas en el tratamiento de la figura de Judas así como en la crítica a los judíos, si nos ceñimos al aspecto formal, el uso de la quintilla vincula la práctica burlesca de Luis Martín con Quevedo.Nótese, además, que la quintilla y la redondilla son las estrofas dominantes en los vejámenes a Judas y que la mayoría de éstos son posteriores a la composición de Luis Martín, por lo que hay que subrayar el papel del poeta antequerano como uno de los primeros cultivadores de este tipo de textos satíricos cuya consolidación se efectuará durante el desarrollo del siglo XVII.

${ }^{53}$ Lara Garrido, 1995, p. 437.
} 
acaban en punto, con lo que la estrofa se convierte en unidad de sentido sin que haya extensiones semánticas que traspasen las fronteras interestróficas. No obstante, el procedimiento generalizado es el de agrupar las quintillas en pequeñas secciones micronarrativas: de la una a la cinco, las agudezas giran en torno al hecho de levantarse de la mesa; de nueve a la doce, el hilo narrativo lo constituye la presencia de san Pedro; y en el fragmento que ocupa de la estrofa trece a la diecisiete el nexo cohesivo gravita sobre la condena de la ambición de Judas y del pueblo en general. El conceptismo de los cuatro versos de Quevedo en «Aquí yace Monsén Diego» o en el soneto «¿Quién es el de las botas, que colgado?» lo sustituye Luis Martín por la chispa ingeniosa y por un sistema de agudezas encadenadas, basadas en la equivocidad de los términos, gracias a un tipo de estrofa que le permitía desarrollar una ideación distinta de lo burlesco.

Observaremos a continuación cómo se hilvanan los principales elementos hasta ahora comentados para formar el tejido burlesco e irónico desde el que se eleva el relieve de la figura de Judas. Las dos primeras quintillas y la penúltima - las que abren y cierran la composición - proponen formulaciones interrogativas que fijan el discurso satírico en una dinámica artificialmente dialógica sustentada en el apóstrofe regular. La interlocución se presenta como instrumento imprescindible de degradación grotesca. Ahora bien, el interlocutor a quien la voz enunciativa exhorta, continua y sistemáticamente, no tiene en ningún momento la posesión de la palabra. El marco dialoga $l^{54}$ es sólo base constructiva del discurso y encubre un alocución monológica en la que la pregunta es respondida por quien la formula. Tal es el caso de la primera (vv. 1-5), a la que se responde con otra pregunta (vv. 6-7), la cual, a su vez, es contestada (vv. 8-10) por el mismo articulador de la interpelación. La interrogación de los vv. 83-85 es meramente retórica.

\footnotetext{
${ }^{54}$ También Quevedo se sirve de las formulaciones interrogativas para el retrato de Judas en el soneto «¿Quién es el de las botas, que colgado» (Quevedo, Poesía original completa, 1999, núm. 540). La formulación dialógica en la organización discursiva del soneto quevediano sirve también al mismo propósito de mera estrategia retórica sobre la que sustentar el entramado del discurso. A diferencia de la «Sátira» de Luis Martín, las preguntas formuladas por el sujeto poético (vv. 1-2, 5, 11) no apelan a Judas sino al lector al que se dirige el soneto. De ahí la primera persona plural del verso cuatro: «Habéis los portugueses despenado». Consigue, de esta manera, la implicación del lector en el universo discursivo por él ideado. Como hemos visto, los textos posteriores a la «Sátira» dedicados al vejamen de Judas no toman el diálogo como forma estructurante de la elocución.
} 
La prédica del divertimento: la figuración carnavalesca de Judas Iscariote en una sátira...

El momento escogido para situar esa fictiva interlocución in praesentia se sitúa justo al fin de la Última Cena: Judas, al ser descubierto por Cristo, abandona la mesa que ha compartido con los apóstoles. A ese esquema dialogal responde el uso de formas verbales en presente, ${ }^{55}$ tiempo dominante en la composición, que alterna con el pasado inmediato - trato de Judas con los fariseos - y con el futuro próximo - cobro del dinero y ahorcamiento - . A esta convivencia de marcos temporales se superpone la alternancia cronológica entre un pasado bíblico donde tiene existencia efectiva la historia de Judas, y la traslación al presente, favoreciendo, de este modo, el dinamismo ya evidenciado por el marco dialogal y por el juego de movimientos de apóstol en torno a la silla.

En esta variación de planos temporales, el pasado sirve a la voz enunciativa para reconstruir burlescamente los avatares previos al instante elegido como punto de inicio de la «Sátira». El momento inmediatamente anterior, la cena, queda marcado por el uso del pretérito perfecto simple del verso «os entró en mal provecho» (v. 10), referido a los alimentos de la cena. Se usa también este mismo tiempo verbal en el v. 12, "ya que os ha escogido Dios», en alusión al momento en que Cristo eligió a Judas entre sus doce apóstoles. El empleo del perfecto compuesto en los versos «Si el dinero habéis jugado / con sisones despenseros» (vv. 41-42) hace referencia al trato de Judas con los fariseos, cuyo desenlace será el prendimiento de Cristo. Paralelamente, contrapuntea el futuro inmediato de la materialización efectiva del trato de Judas cuando entrega a Cristo con el futuro próximo del ahorcamiento: «que no os dará una soga / cuando os queráis ahorcar» (vv. 79-80).

Al dinamismo verbal y al que proporciona un esquema dialógico hay que añadir el juego de movimientos ${ }^{56}$ en las quintillas iniciales. Las cinco primeras se recrean en un juego oscilante entre la quietud y el movimiento, que aspira a semejar la tensión del momento descrito: visualmente, la mesa (v. 4) y la silla (v. 15) sirven de marcas para la creación del ámbito espacial mientras que la abundancia de verbos de movimiento - «caminar» (v. 2), «levantáis»

\footnotetext{
${ }^{55}$ Los ejemplos que podemos aducir son numerosos, de los que pueden ser botón de muestra los siguientes:«os provoca» (v. 1), «estáis satisfecho» (v. 6).

${ }^{56} \mathrm{Ya}$ J. O. Crosby llamaba la atención sobre el reiterado movimiento de Judas en las cuatro quintillas iniciales: «[en la «Sátira a Judas Iscariote»] el estar de camino ocupaba un lugar importante entre las imágenes que caracterizaban a Judas, pues el poeta dedicó los diez versos iniciales a esta actividad y, de manera implícita, la proyectó sobre los quince que siguen» (Quevedo, Sueños y Discursos, 1993, vol. 2, p. 1252).
} 
(v. 4), «sentaos» (v. 11) - y los adverbios — «apriesa» (v. 2), «presto» (v. 15) dinamizan la representación de la figura.

Hemos ido resaltando en los párrafos anteriores una serie de elementos que parecen incidir en un efecto común: la representación «teatral» de Judas en acción. Éstos son el marco dialogal, con esa fictiva interlocución in praesentia, el dinamismo de los juegos temporales y el movimiento de la figura de Judas en la escena de la Sagrada Cena. Se inicia aquí la transformación del apóstol Iscariote en la figura a cuya representación carnavalesca vamos a asistir en las estrofas sucesivas. El «yo discursivo» propone un espectáculo del ridículo, de la burla, un regocijo en la risa, para ir desvelando las facetas encubiertas de quien, a manera de «hipócrita» - en el sentido más teatral de la palabra - , representó durante toda la Sagrada Cena el papel de discípulo fiel. Si Jesús no descubrió a Judas ante los apóstoles, el sujeto poético sí pretende mostrar la verdadera naturaleza ruin del apóstol verdugo de Cristo. Nada mejor que lo carnavalesco para poner de relieve la verdadera intención del apóstol: mostrar el revés de la trama de Judas a través de otra inversión, la de la poesía seria en burlesca.

Desde ese propósito teatral y los recursos que lo evidencian (marco dialogal, juegos temporales, dinamismo verbal), la visualidad ${ }^{57}$ se convierte en un elemento sustancial para el logro de la agudeza y la risa. El verso final de la «Sátira», además de la palmaria comicidad del chiste, presupone la contemplación directa, por parte del sujeto poético, del rostro de quien ya es una figura ridícula: «pues, como quien ha perdido / hacéis cara de ahorcado» (vv. 89-90). A la relevancia de lo visual responde, paralelamente, la fijación en el detalle y la significativa presencia de los objetos tradicionalmente atribuidos a Judas: el dinero (vv. 31, 45, 69), la bolsa (v. 70), la cuerda («cordel», v. 55 y «soga», v. 79) y las botas (v. 75). Cabe matizar aquí que el detenimiento en formas ínfimas, de escaso valor incurre en la comicidad.

Dos elementos se van superponiendoy alternando para la caracterización de Judas: por una parte, la propia acción de la figura durante la «actuación»

\footnotetext{
${ }^{57}$ La pintura de las palabras evocan las representaciones pictóricas de la Sagrada Cena, como $\mathrm{La}$ Cena de Leonardo da Vinci (1495-1498), no tanto las de Castagno y Ghirlandaio. Hay dos aspectos en el cuadro de Da Vinci que pueden ilustrar la lectura que proponemos de la «Sátira» de Luis Martín. Frente a la tradición iconográfica, que solía representar a Judas delante de la mesa y separado del resto de los discípulos, opta Leonardo por incluir al traidor entre los discípulos presentes en la mesa y en actitud de ponerse en movimiento para marcharse. Además, y de acuerdo con sus teorías, Leonardo no se centra tanto en la pintura del rostro como en la actitud y movimiento de los personajes para recoger sus emociones.
} 
La prédica del divertimento: la figuración carnavalesca de Judas Iscariote en una sátira...

en el episodio de la muerte de Cristo y, por otra, las actitudes que de ella se derivan,recogidas por la voz de la enunciación. La seriación verbal - para la acción - , la sustantiva - para el enjuiciamiento de esa acción realizado por el «yo discursivo» - y la adjetiva - para la calificación del sujeto, Judas, que lleva a cabo la acción - vertebran el retrato burlesco:

\begin{tabular}{|c|c|c|}
\hline ACCIÓN DESCRIPTIVA & $\begin{array}{l}\text { ENJUICIAMIENTO del } \\
\text { «yo discursivo» }\end{array}$ & $\begin{array}{l}\text { CALIFICACIÓN DE } \\
\text { LA ACCIÓN: carácter } \\
\text { psicológico }\end{array}$ \\
\hline $\begin{array}{l}\text { A 1) vv. } 4-5 \\
\text { «os levantáis de la mesa / con } \\
\text { el bocado en la boca» }\end{array}$ & $\begin{array}{l}\text { A 2) v. } 11 \text { «Sentaos, mirad } \\
\text { que es mancilla» }\end{array}$ & $\begin{array}{l}\text { A 3) vv. } 21-22 \text { «Y es bien, } \\
\text { pues sois tan rüin, / que } \\
\text { vuestra silla perdáis» }\end{array}$ \\
\hline $\begin{array}{l}\text { B 1) vv. } 28-29 \text { «al confirmar } \\
\text { el contrato, / que lleváis } \\
\text { hurtado a Dios» }\end{array}$ & $\begin{array}{l}\text { B 2) v. } 24 \text { «No ejecutéis } \\
\text { tan mal trato» }\end{array}$ & $\begin{array}{l}\text { B 3) v. } 23 \text { «pues como villano, } \\
\text { al fin» }\end{array}$ \\
\hline $\begin{array}{l}\text { C 1) v. } 34 \text { «pues, cuando por } \\
\text { Dios pedís» }\end{array}$ & $\begin{array}{l}\text { C } 2 \text { ) v. } 39 \text { «que cometéis } \\
\text { simonía» }\end{array}$ & $\begin{array}{l}\text { C 3) v. } 31 \text { «Mas sois picado y } \\
\text { fullero» } \\
\text { v. } 33 \text { «oh cuitado } \\
\text { bordonero!» }\end{array}$ \\
\hline $\begin{array}{l}\text { D 1) v. } 34 \text { «pues, cuando por } \\
\text { Dios pedís» }\end{array}$ & $\begin{array}{l}\text { D 2) v. } 53 \text { «vuestra } \\
\text { pretensión cruel» }\end{array}$ & $\begin{array}{l}\text { D 3) v. } 47 \text { «y siente que sois } \\
\text { aleve» }\end{array}$ \\
\hline $\begin{array}{l}\text { E 1) v. } 62 \text { «en tal precio } \\
\text { vendéis» } \\
\text { v. 69-70« para dinero tan poco } \\
\text { / lleváis tan grande bolsón» }\end{array}$ & $\begin{array}{l}\text { E 2) v. } 71 \text { «Advertid que } \\
\text { es desatino» } \\
\text { v. } 76 \text { «Porque es necedad } \\
\text { pensar» } \\
\text { v. } 81 \text { «Tomad el premio } \\
\text { gentil» }\end{array}$ & $\begin{array}{l}\text { E 3) v. } 83 \text { «mas, ¿que le han } \\
\text { de dar a un vil?» }\end{array}$ \\
\hline
\end{tabular}

Resulta llamativo que Luis Martín prescinda de la caracterización física - por ejemplo, lo bermejo es un lugar común en los escritos satírico-burlescos sobre el apóstol - y sea la deformación moral ${ }^{58}$ la que se va imponiendo en la descripción, por medio de estructuras consecutivas que extraen consecuencias directas y lógicas de los episodios más expresivos de la vida del personaje:

\footnotetext{
${ }^{58}$ Ciertamente, prescinde de cualquier rasgo físico a favor de una enumeración descriptiva de rasgos psicológicos: «ruin» (v. 21), «villano» (v.23), «belleguín» (v. 25), «picado y fullero» (v. 31), «bordonero» (v. 33), «vil» (v. 83) y «cuitado»(v. 86). Éstos se diseminan a lo largo de la sátira a manera de conclusiones sentenciosas que se encauzan a poner de relieve las acciones del personaje, dictadas por la avaricia y la codicia, que justifican, en última instancia, tales calificativos.
} 
«más» (vv. 8, 31, 46, 73, 83); «pues» (vv. 24, 30, 34, 38, 72, 89) y «que» con valor consecutivo (vv. 18, 87). Esa sucesión de acciones que va relacionando el «yo discursivo», junto a su valoración y posterior evaluación del personaje que las ejecuta, se articula en la alternancia de tres paradigmas verbales: verbos de movimiento o que implican algún tipo de acción, verbos valorativos y la calificación que otorgan los copulativos:

\begin{tabular}{|c|c|c|}
\hline ACCIÓN DESCRIPTIVA & $\begin{array}{l}\text { ENJUICIAMIENTO del } \\
\text { «yo discursivo» }\end{array}$ & $\begin{array}{l}\text { CALIFICACIÓN DE } \\
\text { LA ACCIÓN: carácter } \\
\text { psicológico }\end{array}$ \\
\hline $\begin{array}{l}\text { A 1) «caminar» (v. 2) } \\
\text { «os levantáis» (v. 4) } \\
\text { «cenar» (v. 7) } \\
\text { «vais» (v. 9) } \\
\text { «sentaos» (v. 11) }\end{array}$ & A 2) & A 3)«sois $\tan$ rüin» (v. 21) \\
\hline $\begin{array}{l}\text { B 1) «lleváis hurtado» (v. 29) } \\
\text { «Vendéis» (v. 30) }\end{array}$ & $\begin{array}{l}\text { B 2) «No ejecutéis tan mal } \\
\text { trato» (v. 24) }\end{array}$ & $\begin{array}{l}\text { B 3) «pues como villano, al fin» } \\
\text { (v. 23) }\end{array}$ \\
\hline $\begin{array}{l}\text { C 1) «pedís» (v. 34) } \\
\text { «Os dan» (v. 35) }\end{array}$ & C 2 ) «cometéis» (v. 40) & $\begin{array}{l}\text { C 3) «sois picado y fullero» (v. } \\
\text { 31) }\end{array}$ \\
\hline $\begin{array}{l}\text { D 1) «habéis jugado» (v. 41) } \\
\text { «Pedídle» (v. 43) } \\
\text { «Prestará» (v. 45) }\end{array}$ & $\begin{array}{l}\text { D 2) «repara» (v. 46) } \\
\text { «Siente» (v. 47) }\end{array}$ & D 3) «sois aleve» (v. 48) \\
\hline $\begin{array}{l}\text { E 1) «vendéis» (v. 62) } \\
\text { «Llevais» (v. 70) } \\
\text { «Abolló» (v. 84) }\end{array}$ & 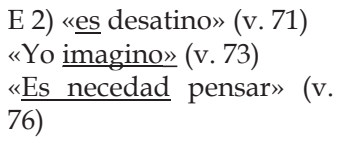 & E 3) \\
\hline
\end{tabular}

El aparente efecto de dispersión provocado por la diseminación de las pinceladas psicológicas y por las acciones deslavazadas se contrarresta con un hilo narrativo de secuenciación seudobiográfica. En los noventa versos que ocupa la «Sátira» están condensados los hechos más reveladores de la vida del apóstol: la Última Cena (vv. 1-25), el acuerdo de Judas con los fariseos para entregar a Cristo (vv. 26-60) y el ahorcamiento final (vv. 76-90). 
La prédica del divertimento: la figuración carnavalesca de Judas Iscariote en una sátira...

\section{UN ITINERARIO BURLESCO}

La «Sátira a Judas Iscariote» empieza, abruptamente, con el insulto genérico $y$, en principio, no individualizador del tipo que se nos presenta: «ladrón» ${ }^{59}$ (v. 1). Junto a ello, se deja patente, también desde el primer verso, el personaje objeto de la «Sátira», cuyo nombre - que ya aparece en el título - se menciona explícitamente en el v. 1: «Judas, ladrón». Ambos aspectos son, pues, indicativos del tono directo que se va a sostener a lo largo de toda la «Sátira»y compartidos por los textos de vejámenes recogidos en los apartados anteriores. El insulto «ladrón» se instituye, de este modo, en el concepto marco al que se van a ir sumando, en estructura apositiva, una serie de calificativos pertenecientes o vinculados al mismo campo semántico: «ruïn» (v. 21), «villano» (v. 23), «belleguín» (v. 25), «picado y fullero» (v. 31), «bordonero» (v. 33), «vil» (v. 83). En cambio, a partir de la quintilla décima, se produce una leve variación en el campo isotópico de lo mezquino, que se reorienta ahora hacia términos que resaltan la necedad del personaje: «es desatino» (v. 71), «es necedad pensar» (v. 76). La base del efecto satírico no se halla, como en Quevedo, en la densidad conceptual ni en la agudeza verbal. Hay en la «Sátira» una tensión continua entre la dispersión que implica la atención al detalle y la fuerza cohesiva que nace de un sistema de repeticiones léxicas y reiteraciones semánticas. Luis Martín va enunciando una serie de conceptos-marco en torno a los cuales despliega un tejido de asociaciones léxicas e imaginísticas interrelacionadas que forman, por esa suerte de lazos semánticos, un entramado compacto al que se irán sumando nuevos concepto-marco y sus asociaciones derivadas. La escuálida línea narrativa, de apariencia seuobiográfica, sirve de bisagra entre los conceptos generales y definidores del tipo que se está pintando. La compacidad de la red asociativa resulta de las reiteraciones verbales, variación sinonímica y palabras que comparten algún sema común o pertenecen al mismo campo semántico y entre las que crea asociaciones inauditas donde reside el efecto de extrañamiento conducente a la risa.

\footnotetext{
${ }^{59}$ Este calificativo, además de ser habitual compañero del apóstol ya desde la Biblia, es un insulto genérico en toda la literatura áurea. Quevedo lo emplea aplicado a Judas en numerosas ocasiones. Véase la nota de Crosby en Quevedo, Sueños y Discursos, 1993, vol. 2, p. 1252. El soneto «¿Quién es el de las botas, que colgado?» va precedido del siguiente título A Judas Iscariote, ladrón de no poquito. No obstante, en la «Sátira» de Luis Martín parece utilizarse como insulto genérico porque en ningún verso posterior vuelve a aludir a elementos que refuercen ese calificativo, posiblemente, por resultarle más interesante la codicia y la traición desde las que introduce, en las quintillas finales, la crítica antisemita.
} 
Un aspecto muy interesante de la técnica descriptiva empleada por Luis Martín se halla en el extrañamiento desde el que hace contemplar al lector las actitudes y acciones más relevantes de la vida del apóstol. La «Sátira» traslada los sucesos elementales de la vida del apóstol pero rompiendo el mecanismo de la lógica, ofreciendo una dinámica nueva que reside, esencialmente, en la construcción verbal del propio discurso satírico.

Se hace necesario, en este punto, examinar el texto desde esos dos ejes vertebrales que hemos señalado: los conceptos-marco y elementos elocutivos que dan cuerpo al tejido de asociaciones imaginísticas, por una parte, y, por otra, atender a esa nueva lógica que el devenir discursivo va imponiendo.

La idea de Judas como el que vendió a Cristo ${ }^{60}$ termina en cosificación, al convertir a Cristo en el objeto robado por Judas y vendido después a los judíos por la nimia cantidad de treinta monedas de plata: «que lleváis hurtado a Dios / pues lo vendéis tan barato» ${ }^{61}$ (vv. 29-30). Judas queda así caracterizado como

\footnotetext{
${ }^{60}$ La imagen definitoria con la que Luis Martín caracteriza a Judas es la del que vendió a Cristo, ya consolidada desde la Biblia. Las demás se suman a ésta: lo vendió por poco dinero, es un traidor, un ladrón y un avaro. Igualmente, éste es el ángulo primordial del retrato de Judas que nos ofrece Quevedo, siguiendo una tradición viene de la Edad Media y el Renacimiento literario español (Quevedo, Sueños y Discursos, 1993, vol. 2, p 1249). Por ejemplo, en el Sueño del Juicio pone en boca del mismo apóstol: «si os vendì, remediè el mundo» (Quevedo, Sueños y Discursos, 1993, vol. 1, p 139); en el Sueño del Alguacil Endemoniado «los Mercaderes que se condenan por uender estàn con Judas» (Quevedo, Sueños y Discursos, 1993, vol. 1, p. 149); y en el Sueño del Infierno: «Vendiste al Justo? Èste es Judas» (Quevedo, Sueños y Discursos, 1993, vol. 1, p. 169). Para finalizar, en el ovillejo A Judas Escariote cuando vendió a Cristo Señor nuestro incide en la misma idea, ya presente desde el título, en los vv. 1-18 (Quevedo, Poesía original completa, 1999, p. 172-173).

${ }^{61} \mathrm{El}$ asunto recurrente de la venta de Cristo por poco dinero en el que insiste Luis Martín - «pues lo vendéis tan barato» (v. 30), «pues cuando por Dios pedís / os dan tan poco dinero» (vv. 3435) y «porque en tal precio vendéis» (v. 60) - se incardina en una tradición muy antigua. Crosby (Quevedo, Sueños y Discursos, 1993, vol. 2, p. 1248) rastrea su presencia en las obras literarias desde la Edad Media hasta Quevedo: está ya en el Libro de buen Amor, en el Cancionero de Juan del Encina, Luis Martín de la Plaza es el siguiente eslabón en la cadena y, finalmente, en el Sueño del Infierno podemos aducir los siguientes ejemplos: «[...] vendiste a tu Maestro, a tu Señor, a tu Dios, por tan poco dinero como èsse?» y un poco más adelante «Y en lo que dezís que fuy traydor y maldito en dar a Cristo por tan poco dinero» (Quevedo, Sueños y Discursos, 1993, vol. 1, pp. 178 y 179). También el v. 18 del ovillejo ya citado (Quevedo, Poesía original completa, 1999, p. 172-173) insiste en la misma idea. Ésta se proyecta en las estrofas finales por medio de la acusación de ruines y codiciosos a los judíos, puesto que fueron ellos los que quisieron hacer de la vida de Cristo un negocio: «Porque es necedad pensar / que la civil sinagoga / de cuartos lo ha de colmar, / porque no os dará una soga/ cuando os queráis ahorcar» vv. 76-80). La misma avaricia achaca Quevedo a los judíos en el Sueño del Infierno: «gente tan ruin como los Judios, que lo era tanto que pienso que si pidiera vn dinero màs por èl, no me lo tomaran» (Quevedo, Sueños y Discursos, 1993, vol. 1, p. 179).
} 
La prédica del divertimento: la figuración carnavalesca de Judas Iscariote en una sátira...

mal «ministro», ${ }^{62}$ que no obra con inteligencia en el trato, al vender algo tan valioso (Cristo así cosificado) por una cantidad insignificante. La comicidad reside, pues, en hacer del trato un intercambio mercantil y de su ejecutor un especulador inhábil. Esta nueva lectura de la traición de Judas es otro elemento que apoya el anclaje del texto en la mentalidad de una sociedad moderna, que ha sustituido el trueque por un sistema de intercambio donde el valor del dinero se convierte en el motor de la vida social. La concreción histórica aleja a la figura de cualquier dimensión teológica y la acerca al ámbito social, de lo ral, si se quiere. Más que de un sustento ideológico sólido, la figuración satírica descansa sobre la inventiva retórica y el virtuosismo asociativo.

El punto de inicio de ese itinerario burlesco ofrecido por la «Sátira» lo constituye la Última Cena en la que los apóstoles reciben el cuerpo y la sangre de Cristo como banquete. La comicidad se logra gracias a distintas fórmulas las cuales aspiran a un efecto de teatralidad tanto en la presentaciónrepresentación de Judas como en la figuración de la escena:

Judas ladrón, ¿qué os provoca

a caminar tan apriesa, que así con furia tan loca os levantáis de la mesa con el bocado en la boca?

¿Es porque estáis satisfecho y no queréis más cenar? no, mas antes yo sospecho que lo vais a vomitar, porque os entró en mal provecho.

(vv. 1-10)

La tradición cristiana instaurado como instante emblemático de la traición de Judas en la Sagrada Cena el momento en que se levanta de la mesa. Luis Martín reduce el climax de la traición a la insignificante cuestión, elevada a primer orden, del abandono de la silla por Judas que podría, así, quedar sin asiento. En este caso, es el encumbramiento de un detalle ínfimo el que provoca el desconcierto y/o extrañamiento.

\footnotetext{
${ }^{62}$ En este punto difiere del soneto de Quevedo titulado A Judas, ladrón no de poquito: «¿y entre los cinco mil no hurtó aquel día? / Fue Judas gran ministro, no ratero: / las migajas dejó porque atendía / a embolsarse su dueño todo entero». La deconstrucción burlesca del acto de traición en la «Sátira» lleva aparejada la reinvención de un personaje necio que no obtiene de una acción tan vil el resultado esperado.
} 
Todos los elementos pertenecientes al ritual de la cena, sacralizados por el dogma católico, se convierten, también, en materia óptima para el chiste. Los manjares del banquete, pan y vino, después transformados en sangre y cuerpo de Cristo por el sacramento de la Eucaristía, se transmutan en secreción nauseabunda desde un acercamiento irreverente a las cosas sagradas y mediante el enlace de lo sagrado a lo más ínfimo, de lo espiritual a lo puramente material.

La comparación y metáfora degradadora se usa también como recurso para la desacralización del simbolismo de la Sagrada Cena: la reunión de los apóstoles se figura en «cuadrilla» (v. 13).

Sentaos, mirad que es mancilla, ya que os ha escogido Dios por uno de su cuadrilla, por ser mal jinete vos, tan presto perdáis la silla

(vv. 11-15)

y, partir de aquí se inicia el despliegue de asociaciones metafóricas: si los allí reunidos son una cuadrilla, cada apóstol es un jinete, y Judas, por no ser ni buen apóstol ni buen jinete, pierde la silla - la de la mesa y la de la montura del caballo - y, en una transposición metafórica más, lo que acaba perdiendo es su lugar entre los doce discípulos de Cristo. El tejido asociativo y metafórico se va trenzando de la siguiente manera y tiene como finalidad ese común rebajamiento burlesco de la reunión sagrada:

\author{
Plano real \\ Sagrada Cena \\ cuerpo y sangre de Cristo \\ reunión de los doce apóstoles \\ Judas \\ silla
}

\author{
Plano metafórico \\ banquete \\ náusea \\ cuadrilla \\ jinete \\ silla de montar
}

Acaba el retrato de Judas en la Sagrada Cena con la frase proverbial: «y os quedaréis de la agalla» ${ }^{63}$ (v. 20).

\footnotetext{
${ }^{63}$ Anota J. M. Morata (Martín de la Plaza, Poesías completas, p. 287) lo siguiente sobre esta locución proverbial, tomado del Diccionario de Autoridades: «es frase tomada "para dar a entender que alguno se quedó burlado, y desvanecida alguna esperanza en que estaba fundado" ». Covarrubias habla del origen del proverbio "Quedóse de la agalla»: «quando uno queda asido, o preso, o frustrado de su pretensión por semejanza al pez que queda preso en el anzuelo por la agalla. Que es ésta la abertura que tiene entre el cuerpo y la cabeza y por la que quedan asidos a la red».
} 
La prédica del divertimento: la figuración carnavalesca de Judas Iscariote en una sátira...

En esta primera secuencia de la «Sátira» encontramos compendiados los recursos estilísticos básicos que conforman el modus escribendi burlesco del poeta antequerano. Las figuras más utilizadas son la dilogía y la silepsis, que sirven de basamento a la acumulación de equívocos, los cuales se van encadenando para crear dobles sentidos, los cuales, referidos a distintos planos por una serie de variaciones metafóricas, son el sustento de la burla y la comicidad derivada de ella. La doblez de la actitud de Judas se convierte también en doblez verbal y conceptual en los juegos dilógicos, a la vez que los contextos metafóricos se van haciendo más complejos a medida que la «Sátira» avanza, a partir de asociaciones, si no ingeniosas, al menos inusitadas. Todo ello sostenido por el tono irónico a que da lugar la continua equivocidad de los términos que van concurriendo. Los coloquialismos y frases proverbiales contribuyen a la degradación lingüística exigida por el género burlesco para la canónica acomodación de materia y estilo.

La quintilla número cinco pasa por ser una estrofa de transición. Acaba con el episodio de la silla en la Última Cena para dejar paso al del trato ${ }^{64}$ de Judas, que empieza con una enumeración descriptiva y acumulativa de calificativos negativos: «rüin» (v. 21), «villano» (v. 23), prácticamente sinónimos,

\footnotetext{
${ }^{64}$ La insistencia en el «mal trato» (v. 26) se perpetúa en las estrofas siguientes: «Pues, cuando por Dios pedís / os dan tan poco dinero (vv. 34-35); «que aún en todo no tenéis / para un juego del rentoy» (vv. 64-65); «para dinero tan poco» (v. 69). Además de la tradición literaria ya codificada a que aludíamos de la venta de Cristo por poco dinero y de su rentabilización en la «Sátira» de Luis Martín al reforzar la caracterización de Judas como necio, habría que considerar varios factores sociológicos que otorgan a esta representación de Judas una dimensión social que la aleja de la ambientación bíblica y la enclava en un mundo de pícaros. Ya mencionábamos la relevancia del valor del dinero en la sociedad de inicios del XVII y la indiscutible habilidad que se reconocía en la época a los judíos para la administración de la economía. La presentación del trato de Judas con los fariseos como un intercambio poco inteligente por parte del apóstol refuerza ese valor del dinero, a la vez que apoya la crítica antijudaica, que cobra especial virulencia en las quintillas finales. Está ampliamente documentado el importante papel que desempeñaron los judíos como figuras sobresalientes en la administración de la hacienda real española en el período áureo (Glaser, 1954, p. 39).

Quevedo, en el soneto al que ya nos hemos acercado desde varias perspectivas, «¿Quién es el de las botas, que colgado?», utiliza la imagen político-administrativa de Judas como presidente de la hacienda y como "ministro», partiendo de la consideración de éste como despensero de los apóstoles. Dice en este soneto: «y presidió la hacienda interesado» (v. 8) y en el v. 12 «Fue Judas gran ministro, no ratero». Era Judas el ministro de Cristo, el que se ocupaba, en consecuencia, de la «hacienda» de los apóstoles. Quevedo da un salto del ámbito bíblico a la dimensión social, y desde ahí a la política era fácil la traslación. La figura de Judas adquiere, de esta forma, una nueva dimensión: la del personaje bíblico pero, también, el ladrón contemporáneo. No hay duda de que Judas tendría muchos modernos descendientes en la España Imperial.
} 
y «belleguín» (v. 25). Subyace en esta quintilla la oposición entre caballero y villano matizada en el verso «de apóstol en belleguín» (v. 25): los dos primeros términos de la oposición, «caballero» y «apóstol» comparten el sema 'ir a caballo' mientras que «villano» y «belleguín» son los que van a pie.

Los conceptos-marco se adscriben, sobre todo, a la seriación adjetiva y distribuyen la materia discursiva en una estructura equilibrada en cuanto a la disposición estrófica:

- Las quintillas 1-5 (vv. 1-25) escenifican la Última Cena. La idea básica de Judas como «ladrón» en el v. 1 sirve de encuadre al discurso satírico completo.

- Los vv. 26-65, que abarcan las estrofas 6-13, recrean el trato de Judas con los judíos. Los calificativos de «picado» y fullero» (v. 31) y «bordonero» (v. 33) enmarcan estas estrofas.

- El tercer bloque, formado por las quintillas 14-17 (vv. 66-90), tiene como núcleo la codicia de Judas, que se hace extensiva al pueblo judío reconduciendo, de esta manera, la "seudocrítica" desdela personalización en Judas hacia el conjunto del pueblo hebreo. La apreciación como «vil» (v. 83) supone el climax en esa enumeración de términos valorativos aplicados al personaje.

Las adjetivaciones de «picado» y «fullero» (v. 31) abren todo un abanico de secuencias metafóricas relacionadas con el ámbito del juego:

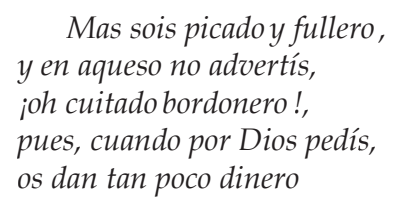

(vv. 31-35)

«Fullero» (v. 31), según Covarrubias, es 'el jugador de naipes o dados que, con mal término y conocida ventaja, gana a los que con él juegan, conociendo las cartas, haciendo pandillas, jugando con naipes y dados falsos, andando de compañía con otros que se entienden, para ser, como dicen, tres al moino'. El elemento coordinante copulativo «y» que une «picado» a «fullero» atrae la significación del primer término hacia la esfera semántica de los juegos de azar. En el Diccionario de Autoridades se recoge del verbo «picar» 
La prédica del divertimento: la figuración carnavalesca de Judas Iscariote en una sátira...

este significado: 'En el juego de los cientos vale contar el que es mano sesenta puntos, cuando en las jugadas había de contar treinta, sin haber contado punto alguno el contrario'. Dentro de este mismo campo semántico está el chiste de los vv. 64-5: «que aun en todo no tenéis / para un juego del rentoy».

El mundo del juego ${ }^{65}$ está asociado a los maleantes y al universo de la picaresca, igual que la figura del «bordonero ${ }^{66}$ con la que se compara a Judas en el verso 33. Las dilogías encadenadas, pertenecientes a distintos espacios de significación, aunque interrelacionados - en este caso el de los tramposos y el de los vagabundos-, establecen vínculos que las engloban en una metáfora aglutinadora y dilatada que llega a abarcar el conjunto completo de la «Sátira». La composición de Luis Martín no tiene la densidad conceptual ni la perfección constructiva de Quevedo, pero sí sabe encontrar el antequerano un espacio propio en que desarrollar, tanto en el plano de la dispositio como en el de la elocutio, originales resortes poéticos de la risa.

El chiste, junto a la dilogía, se alza en el recurso más recurrente. Tal es el caso del que se compone en torno al verbo "pedir», en el que la conjunción de los dobles sentidos y de la broma del chiste aspira a mostrar la doble faz de las acciones del apóstol: Judas como «bordonero» pide caridad, pero como apóstol y como villano pide a los judíos una recompensa por vender al hijo de Dios: «pues, cuando por Dios pedís, / os dan tan poco dinero» (vv. 34-35). Y en el asunto eclesiástico como materia para el chiste encuentra Luis Martín otro venero del que mana la carcajada. Tal es el caso del gracejo en torno a la palabra «suspensión» del verso 40: suspensión es la 'censura eclesiástica o pena política que en todo o parte priva del uso del oficio o beneficio o de sus goces y emolumentos' (Diccionario de Auoridades), pero, de igual forma, estar suspendido es estar el ahorcado pendiente de la soga. En torno a la equivocidad de todos estos términos compone Luis Martín la figuración de Judas como un personaje del inframundo de la España del Siglo de Oro.

\footnotetext{
${ }^{65}$ En cuanto a la red de asociaciones metafóricas vinculadas al campo semántico del juego hay un fragmento del Sueño del Juicio que puede arrojar luz sobre ello: «Dijo vn Diablo: Judas es Apostol descartado [...] Naydie mire que vamos a partido, y tomamos infinitos siglos de purgatorio El diablo como buen jugador, dijo: Partido pedis? No teneis buen juego» (Quevedo, Sueños y Discursos, 1993, vol. 1, p. 135). Crosby comenta en relación a este pasaje y a la «Sátira» de Luis Martín que «en sentido literal, coincide la imagen de descartado con lo que en 1603 dijo Luis Martín de la Plaza en su Sátira a Judas [en los versos «tan presto perdáis la silla» y "que vuestra silla perdáis»]» (Quevedo, Sueños y Discursos, 1993, vol. 2, p. 991).

${ }_{66}$ 'El que disimulado con el hábito de peregrino y el bordón anda vagando por el mundo por no trabajar' (Covarrubias)
} 
A otro personaje bíblico, el mismísimo Padre de la Iglesia, retrata Luis Martín de la Plaza en quince versos. La técnica descriptiva en este «microrretrato» revela idénticos recursos a los del «macrorretrato» de Judas en el que está integrado. San Pedro es descrito por las actitudes que el «yo discursivo» le presupone a la figura bíblica: la generosidad - «pedidle a Pedro prestado / que él os prestará dineros / aunque empeñe su terciado» (vv. 43-44) - y la fidelidad a Cristo. Pero enseguida sobreviene la degradación burlesca al caracterizarlo de «buen viejo» (v. 46) y poner en acción un bravucón que no dudaría en arremeter contra Judas si tuviera conocimiento de sus verdaderos propósitos:

Mas si el buen viejo repara $y$ siente que sois aleve, tened por cosa muy clara que antes que Cristo cruz lleve la llevaréis por la cara.

Y aun quizá os irá con él tan mal, si a saber alcanza vuestra pretensión crüel, que no deje la venganza encomendada al cordel

(vv. 46-55)

En torno a la bisemia de la palabra «cruz» establece un chiste fácil: la cruz que Cristo llevará a cuestas hasta el Calvario y en la que será crucificado y el dibujo de la cruz o persignum crucis que san Pedro dejará marcado en el rostro de Judas con su espada - o con su cuchillo-a la manera en que se hacían en los duelos. La convivencia de dos significados tan dispares -el sagrado de la cruz en que Cristo murió y el de la señal con que se marcaba al adversario en las justas - en un mismo significante, acentúa, por contraste, el efecto burlón. Vuelve a insistir en los versos siguientes en la misma imagen de san Pedro como bravucón: «que no podrán resistillo / cuantos se pongan delante, / para que con su cuchillo, / primero que el gallo cante, / no os corte a vos el gallillo» (vv. 56-57).

El juego de palabras, tanto en el plano del significante como del significado, en torno a los lexemas «gallo»-«gallillo» clausura el retrato de san Pedro. De nuevo recurre el poeta antequerano a la doble alusión en la mención del «cordel» (v. 55), pues si bien «cordel» es la soga con la que Judas 
La prédica del divertimento: la figuración carnavalesca de Judas Iscariote en una sátira...

se ahorcó, también - dice Covarrubias - 'tomóse la metáfora de los cordeles que aprietan a los que ponen a qüistión de tormento'.

Las dos siguientes quintillas, la trece y la catorce, sonclaves para determinar el posicionamiento del «yo discursivo» $y$, por ende, la intencionalidad de un discurso. En estas estrofas, frente a las anteriores, posee especial relieve la voz enunciativa, cuya presencia queda evidenciada en el empleo de la primera persona verbal y los pronombres correspondientes a ella:

Con vos enfadado estoy, porque en tal precio vendéis a quien yo el alma le doy, que aun en todo no tenéis para un juego del rentoy.

Y así, con justa razón a cólera me provoco de ver que en esta ocasión para dinero tan poco lleváis tan grande bolsón.

La oscilaciones en la actitud de la voz enunciativa a que hacíamos referencia al inicio crea un juego de ambigüedades muy interesante, ya que en la problematicidad del sujeto poético radica, en gran parte, el sentido último de la «Sátira» de Luis Martín. En estas últimas estrofas, la presencia de la primera persona cobra especial protagonismo y relevancia en el acto comunicativo, como se desprende de la acumulación de referencias - mucho más neutras en las quintillas precedentes - a esa primera persona verbal y los pronombres personales que la acompañan: «enfadado estoy» (v. 61), «a quien yo el alma le doy» (v. 63) y «a cólera me provoco» (v. 67).

Nada ocioso hay, pues, en el lugar que estas quintillas - trece y catorce - ocupan en la distribución estrófica de la «Sátira». Se ubican justo después del episodio de la «posible venganza» de san Pedro y antes de las tres estrofas que centralizan la crítica antijudaica. Esta colocación, en una zona marcada del poema, responde a distintos propósitos comunicativos: primero, el de situar la actitud de san Pedro en el mismo plano que la del sujeto poético - también se invita al lector implícito a colocarse en ese lado de la oposición binaria primera / segunda persona que la «Sátira» establece - ; y, segundo, el de introducir la crítica a los judíos en las tres quintillas siguientes y antes de la estrofa de cierre en la que se recupera la preeminencia de la primera persona: «quiero dejados, cuitado» (v. 86) y «por la vaya que os he dado» (v. 88). 
A diferencia de la segunda persona enunciativa, que aparece identificada con la persona de Judas desde el título y el primer verso, la indeterminación de la primera persona hace aparecer al sujeto poético como simple evocación de un estado de conciencia que se opone sistemáticamente al del «tú» al que apela. Ya hemos insistido en varias ocasiones en que el apóstrofe reiterado es puramente retórico, pues, en sentido estricto, nunca se espera respuesta a las preguntas formuladas. No es más que un artificio que, en última instancia, aspira a mover el ánimo del lector para que se sitúe en un lugar determinado de ese sistema contrapositivo que se va gestando entre las dos instancias de la enunciación y, a la vez, mostrar su propio estado de conciencia - sincero o no, ello no afecta a la dinámica textual - , determinado por el «enfado» (v. 61) o la «cólera» (v. 67). Se atrae, de esta manera, al lector hacia el sistema de valores que se va conformando en torno a esa primera persona.

El hecho de que Judas no tome la palabra en ningún momento puede ser índice de la propia indignidad del personaje cuya voz no admite crédito alguno. ${ }^{67}$ No obstante, también podría argüirse de la falta de respuesta que el apóstrofe se dirige más bien a una imagen, como una de esas sombras del Infierno dantesco o quevediano. Judas, en la ficción enunciativa, aún no ha muerto - como muestran los versos «pues, como quien ha perdido / hacéis cara de ahorcado» (vv. 89-90) - y podría tomar la palabra, pero no tiene más entidad que la burlesca y carnavalesca que el sujeto poético le ha otorgado. Otra implicación que se deduce de este esquema discursivo es la actualización de la figura, que se sitúa «vivificada» - fruto de esa «representación - ante los ojos del lector para lograr, de manera más efectista, la evidentia de una actitud que se sitúa al margen del sistema moral y de valores imperante.

Se hace necesario en este punto, la revisión de las distintas modulaciones, en las sucesivas situaciones enunciativas, de la voz discursiva hacia la figura a la que dirige su alocución. Nos referíamos anteriormente a las inflexiones en la tonalidad enunciativa con la que el «yo discursivo» se dirigía a Judas, pero vamos a analizarlo ahora con algo más de detenimiento en los puntos fundamentales y a la luz de los nuevos elementos que hemos venido comentando. El esquema de tales variaciones es éste que exponemos seguidamente. El tono de las primeras quintillas, las que recrean la escena de la Sagrada Cena, si bien es imperativo,

\footnotetext{
${ }^{67}$ Quevedo sí le da la palabra en el Sueño del Infierno, porque el mundo infernal se rige por leyes distintas que permiten tales licencias ficcionales.
} 
La prédica del divertimento: la figuración carnavalesca de Judas Iscariote en una sátira...

oscila hacia la condescendencia del consejo sintetizada en el v. 17: «iquién me mete en avisaros?». En la segunda sección, dedicada al trato de Judas con los fariseos, la relación entre las dos instancias discursivas se establece a través de la acumulación de calificativos negativos aplicados a Judas. La parte final concentra la virulenta invectiva hacia los judíos a partir del embate contra la codicia de Judas. La quintilla de cierre fluctúa, nuevamente, hacia cierta benevolencia que entronca con la condescendencia inicial.

Esta fluctuación conduce a cuestionar el verdadero valor - no extratextual sino estrictamente discursivo - de los versos «con vos enfadado estoy» (v. 61) y «a cólera me provoco» (v. 67). Aunque la confrontación, sistemática y continuada, de la primera y segunda persona deja clara la distancia entre ambas, el giro hacia un tono grave en estas quintillas trece y catorce, con la declaración explícita de la contrariedad del sujeto discursivo, responde, probablemente, a la búsqueda de una justificación intratextual del discurso mismo, calificado unos versos más adelante como «vaya» (v. 88). La justificación metadiscursiva de la retahíla burlesca de la «Sátira» se ampara en un «yo cristológico» que, desde su conciencia cristiana, se ve impelido a la denuncia. El proceso genético del discurso satírico se explica desde un alma lastimada que con «justa razón» - en las estrofas precedentes y las que siguen de invectiva antijudaica se encuentran esas razones - y, desde la cólera y el enfado, articula tal discurso satírico.

No obstante, y pese al tono grave de estos versos, no dudamos en afirmar que el tratamiento que la figura de Judas recibe en la «Sátira» por parte del «yo lírico» es indulgente. Este es un elemento diferencial de marcada significación que distancia de la «Sátira» de Luis Martín de la virulencia que se adscribe a los textos de vejamen.

\section{La prédica antijudaica}

En las estrofas finales se intensifica la crítica antijudaica por parte de esa instancia discursiva en primera persona que se ha presentado en las dos quintillas anteriores como un «yo reverencial» y «cristológico». Ahora arremete no sólo contra Judas, sino contra el pueblo judío en general como responsable de la muerte de Cristo. En este punto, también se distancia la «sátira» de Luis Martín de los vejámenes a Judas, centrados de forma exclusiva en este personaje y sin apertura a otro tipo de consideraciones. 
A partir del juego pseudoetimológico que equipara Judas a judío, introduce la prédica contra el pueblo hebreo, la cual vertebra en tres chistes, cada uno en una estrofa: ${ }^{68}$

La primera:

Advertid que es desatino, pues sin blanca ha de volver; mas, a lo que yo imagino, del cuero queréis hacer unas botas de camino

(vv. 71-75)

introduce el motivo de la bolsa con que Judas fue a recibir el pago de la «venta» y que es el objeto al que tradicionalmente se ha acudido, de manera insistente, para simbolizar la ambición del apóstol. La bolsa - que con el sufijo aumentativo se ha convertido en «bolsón» (v. 70) - , tan grande como la propia codicia $^{69}$ de Judas, quedará, finalmente, vacía de acuerdo con la predicción del sujeto poético. Ya que la bolsa no cumplirá la misión a que estaba destinada, su material - el cuero - sólo servirá para hacerse unas «botas de camino» (v. 75).

Si la bolsa ha sido un elemento de presencia constante en las reescrituras literarias - y artísticas en general - de la figura de Judas, el motivo de las botas es novedoso en la caracterización del apóstol en torno a 1600. Crosby señala la «Sátira» como el primer ejemplo de la atribución a Judas de unas botas: «Aunque Quevedo afirma que había un "refrán" que decía, Las votas de Judas, no he encontrado ningún ejemplo antes de 1603, cuando lo empleó

\footnotetext{
${ }^{68}$ En estas quintillas finales se concentran todos los objetos que tradicionalmente configuran los atributos identificadores de la figura de Judas: la bolsa y la cuerda. El otro elemento caracterizador, las botas, plantea una serie de interrogantes a los que intentaremos ir respondiendo.

${ }^{69}$ La avaricia - como marcará Luis Martín en los vv. 76-80 - es un estigma que el pensamiento antisemita siempre ha hecho pesar sobre los judíos y la bolsa se ha empleado, tradicionalmente, para simbolizarla. Ya aparece en san Juan (XII, 6) aplicado a Judas como «ladrón», y desde entonces «por su codicia es pintado a menudo con una bolsa de dinero» (Martín Fernández, 1979, p. 135). Crosby también insiste en la ascendencia bíblica del motivo al argumentar que los satíricos españoles tomaron la imagen de las bolsas del evangelio «haciendo de ellas símbolo de la codicia, el latrocinio y la traición (Quevedo, Sueños y Discursos, 1993, vol. 2, p. 1245). La bolsa también simbolizaba la cuerda con la que Judas se ahorcó, puesto que «las bolsas llevaban una correa larga que permitía que el individuo las llevara colgada del hombro» (Quevedo, Sueños y Discursos, 1993, vol. 2, p 1245). Localizamos el siguiente ejemplo en Quevedo: «o con la bolsa, ahórcate Judas» (Quevedo, Poesía original completa, 1999, p. 94, núm. 125, v. 14)
} 
La prédica del divertimento: la figuración carnavalesca de Judas Iscariote en una sátira...

Luis Martín de la Plaza en su Sátira a Judas Iscariote». ${ }^{70}$ Esta afirmación del hispanista estadounidense hay que considerarla con cierta reserva, puesto que no revisa el corpus manuscrito de composiciones sobre Judas, por ejemplos los vejámenes, ni tampoco menciona haber revisado comedias, sermones etc. que tienen por objeto este personaje bíblico. Quevedo ${ }^{71}$ alude a ellas en el Sueño del Infierno y pone en boca del falso discípulo de Cristo una razón factible para explicar el valor de este elemento: «quisieron significar poniendome votas que andaua siempre de camino para el infierno, y por ser despensero». En otro pasaje del Sueño del Infierno ${ }^{72}$ las asocia el autor del Buscón a un refrán: «¿Las votas de Judas? No porque ya las truge» y continúa explicando: «Esta fue la causa y no la que algunos han colegido de verme con votas, diziendo que era Portugués». ${ }^{73}$

No obstante, si podemos atestiguar, junto a Crosby, que las botas no aparecen mencionadas en ninguno de los vejámenes que he revisado atentamente, lo que nos lleva a emprender la tarea de indagación de referentes a los que pudo acudir Luis Martín para recoger este motivo en su composición y a qué motivación responde tal atributo. Para ello consideraremos dos perspectivas, legitimadas por las palabras Quevedo. La primera está en relación con la indumentaria y la otra con el peregrinar o caminar eternamente como forma de castigo. Junto a ello, como explicaremos enseguida, hay que considerar la posible intrusión de la leyenda del Judío Errante gracias a los resortes comunes que permiten tal asociación de las dos figuras.

La sátira del XVII abunda en la indumentaria como mecanismo de burla. Entre la nómina de elementos que constituían el vestido de los

\footnotetext{
${ }^{70}$ Quevedo, Sueños y Discursos, 1993, vol. 2, p 1253.

${ }^{71}$ Quevedo, Sueños y Discursos, 1993, vol. 1, p. 179.

${ }^{72}$ Quevedo, Sueños y Discursos, 1993, vol. 2, p 1253.

${ }^{73}$ La obra de Quevedo acaba por codificar las botas como uno más de los atributos identificadores de la figura de Judas. A los pasajes aclaratorios sobre tal motivo que hemos citado en el Sueño del Infierno se añaden los textos poéticos que incluyen las botas en el retrato de Judas. Tal es el caso de las Décimas A una mujer que besó a un caballero, estando mirando un Judas (Quevedo, Poesía original completa, 1999, p. 702 núm. 674, vv. 24-26: «le daré bolsa y dinero, / un comprador y un ropero, / botas le daré después». También en el romance Efectos del amor y los celos (Quevedo, Poesía original completa, 1999, p. 978, núm. 768, vv. 97-98,): «y el Judas de los amores, / que sin dinero ni botas, / el umbral de Anaxarete / la requebraba de soga». A éste hay que añadir el también romance Refiere las partes de un caballo y de un caballero número (Quevedo, Poesía original completa, 1999, p. 796, núm. 707, vv. 71-72: «pues se acuerda de las botas / des discípulo traidor». Y, por último, aparece este motivo en el soneto «¿Quién es el de las botas, que colgado?».
} 
portugueses estaban incluidas las botas. ${ }^{74}$ Pero hay una razón más que apoya la mención a las botas como rasgo de la indumentaria de los portugueses y que, además, conectaría el motivo de las botas con el contexto general de crítica antijudaica de estas estrofas finales. Reside éste en un lugar común en las invectivas antisemitas, el de la equiparación portugués y judío, propiciado por una situación histórica muy concreta: después de la expulsión de los judíos de España, muchos de ellos se establecieron en Portugal ${ }^{75}$ por la mayor flexibilidad del país vecino hacia sus costumbres y prácticas religiosas. Pero no sólo la portuguesa sino también la vestimenta castellana, ${ }^{76}$ aduce Crosby ${ }^{77}$ contenía las botas. Por estar éstas ligadas a la gala y riqueza de los colores del vestido de camino la atribución resulta aún más burlesca.

Otro argumento complementario se suma al esclarecimiento de la alusión a las «botas». Quevedo, unos años después de la «Sátira» de Luis Martín, en el Sueño del Infierno ${ }^{78}$ ponía en boca de Judas estas palabras, ya citadas anteriormente, sobre el significado de las botas: «mas quisieron significar poniéndome votas, que andaua siempre de camino para el Infierno, y por ser Despensero». ${ }^{79}$ Este motivo del andar errático como castigo conecta

${ }^{74}$ Testimonio de ello ofrece Quevedo en el «Poema heroico de las necedades y locuras de Orlando el Enamorado» (Quevedo, Poesía original completa, 1999, núm. 875, p. 1227, vv. 169-172): «Portugueses, hirviendo de guitarras, / arrastrando capuces, vienen listos, / compitiendo la solfa a las chicharras, / y todos con las botas muy bienquistos».

${ }^{75}$ «En Portugual las autoridades trataron a los conversos forzados con menos rigor, y por eso persistieron allí costumbres judías» (Glaser, 1954, pp. 40-41). Igualmente, recoge Glaser (1954, p. 41) una cita de Quevedo en La rebelión de Barcelona sobre los judíos: «la cosa que más a mano hay en Portugal».

${ }^{76}$ Quevedo alude a este vestido en la jácara Villagrán refiere sucesos suyos y de Cardencha (núm. 853, vv. 11-12, p. 1133) «jayanes de arredro vayas, / cuya sed a todas horas / se calza de vino añejo, / sin ir de camino botas» y el baile Los Borrachos (núm. 873, vv. 47-48, p. 1214 de la edición de Blecua): «Siendo borrachos de asiento, / andan ya de sopa en sopa, / con la sed tan de camino, / que no se quitan las botas». Ya Quevedo había achacado el uso de las botas a «una célebre coquetería vestuaria de los portugueses» (Vilar, 1978, p. 107) tanto en los Sueños como en sus escritos poéticos, por ejemplo, el soneto «¿Quién es el de las botas, que colgado»: «Habéis los portugueses despenado» (Quevedo, Poesía original completa, 1999, núm. 540, p. 531 v. 4).

${ }_{77}^{7}$ Quevedo, Sueños y Discursos, 1993, vol. 2, p. 1253: «el vestido castellano de camino incluía las botas».

${ }^{78}$ Quevedo, Sueños y Discursos, 1993, vol. 1, p. 179.

${ }^{79}$ Quevedo también esgrimía, entre las razones de Judas para llevar las botas, junto a su peregrinar continuo camino al infierno, la de ser despensero. Respecto a la adscripción de las botas a los despenseros Crosby propone la siguiente explicación: «Insiste en la correlación estrecha entre los despenseros y las botas [...], basándose no sólo en el oficio de Judas como apóstol encargado de las provisiones, sino en los repetidos y bien conocidos recorridos de los de los despenseros en busca de artículos para la despensa del amo» (Quevedo, Sueños y Discursos, 1993, vol. 2, p 1255). 
La prédica del divertimento: la figuración carnavalesca de Judas Iscariote en una sátira...

con el dinamismo de la escena de la Sagrada Cena y al que Crosby hace referencia: «[en esta Sátira a Judas Iscariote] el estar de camino ocupaba un lugar importante entre las imágenes que caracterizaban a Judas, pues el poeta dedicó los diez versos iniciales a esta actividad, y de manera implícita la proyectó sobre los quince que siguen».$^{80}$ Desde que Judas se levantó de la mesa se convierte en un caminante ${ }^{81}$ eternamente castigado y arrastrando el peso de la culpa. Para ese caminar eterno necesita el apóstol las botas. A esta relevancia del movimiento en los primeros versos, es pertinente añadir que otro vocablo asociado a la idea de vagar y errar - también a la de dinero y, por tanto, a la bolsa - , es el de «bordonero» (v. 33). Para explicar esta idea del movimiento así como la imagen de 'estar de camino', se remonta Crosby a los relatos bíblicos de san Juan (XIII, 21-27, 30) y san Lucas (XXII, 4), los cuales no ofrecen, a mi parecer, un sustento explicativo lo suficientemente sólido. ${ }^{82}$

La idea quevediana de un Judas que está siempre de camino hacia el Infierno en una suerte de peregrinatio eterna, se encuentra también en Luis Martín antes que en Quevedo. Un posible antecedente para esta imagen de peregrino eterno atribuido a Judas encuentra Crosby «en el dicho siciliano "Giuda non mori mai"», que se hace eco de la creencia popular de que el alma de Judas está condenada a vagar «per aria senza fermarsi mai altro que per guardare e contemplare qualque tamerice». ${ }^{83}$

Si no directamente el motivo de las botas, sí la idea del peregrinar eternamente evoca otros personajes castigados a vagar hasta el fin de los tiempos por ultrajar a Cristo. El caso más evidente lo constituye la leyenda del Judío errante. ${ }^{84}$ Crosby sugiere como trasfondo explicativo de la insistencia en el movimiento, en las cuatro quintillas iniciales, la leyenda del Judío Errante y la de san Juan evangelista, que espera en la tierra la nueva venida de Cristo. Por ello, sugiere la incorporación de Judas a toda esa tradición de peregrinos condenados a vagar eternamente (en la clasicidad Calisto e Io, Caín, el Judío

\footnotetext{
${ }^{80}$ Quevedo, Sueños y Discursos, 1993, vol. 2, p. 1252.

${ }^{81}$ Sirvan de ilustración estos versos de la «Sátira»: «caminar tan apriesa» (v. 2), «después no habrá en que sentaros / y os quedaréis de la agalla» (vv. 19-20).

${ }^{82}$ Lo único que san Juan recoge es que en cuanto tomó Judas el último bocado salió y era ya de noche. No parecen estas palabras lo suficientemente determinantes para sustentar una argumentación como la que Crosby propone.

${ }^{83}$ Quevedo, Sueños y Discursos, 1993, vol. 2, p. 1254.

${ }^{84} \operatorname{Vilar}(1978$, p. 107) propone respecto al soneto de Quevedo «¿Quién es el de las botas, que colgado», que la alusión a las botas puede tratarse «de una confusión difusa y posible con el Judío errante».
} 
errante en la cristiana, etc.): «a las tradiciones cristianas hay que añadir la de Judas, por pocos que sean los testimonios de su supuesta peregrinación eterna» ${ }^{85}$. Sólo tres son los testimonios manejados por el estudioso de Quevedo para sostener tal peregrinación eterna de Judas: el relato de san Juan - que no resulta concluyente a nuestro juicio - la propia «Sátira» de Luis Martín de la Plaza y el refrán siciliano mencionado. Más bien, lo que Luis Martín propone en su «Sátira» consiste, sencillamente, en equiparar la figura de Judas con la del Judío errante o bien con la de su descendiente español, Juan de Espera en Dios: las botas, la insistencia en el movimiento y, especialmente, el motivo de las blancas, introducido en el v. 72, favorecen el supuesto de que Luis Martín tenía en mente este tipo de figuras erráticas, forjadas por las distintas tradiciones folclóricas nacionales y que fusiona con la historia del propio Judas.

La similitud de los dos personajes en el hecho de que ambos ultrajaron a Cristo, aunque de diferente manera, y la comunión de los elementos que los caracterizaban (la bolsa, las monedas, las botas) viabiliza la permeabilidad entre ambos personajes. Además, se adecua estrechamente al contexto de crítica antijudaica en que se ambientan estas estrofas. Tanto Judas, que vendió a Cristo con unas monedas, como el impío zapatero que viendo a Cristo sufriendo camino del Calvario no se compadeció de su dolor, ejemplifican idéntica vileza.

En definitiva, estos dos motivos, el de las botas y el del peregrinar eterno, que configuran un novedoso retrato del apóstol, cobran plena significación, entonces, explicados desde la historia del Judío errante, que se hace aún más palmaria al mencionar Luis Martín la «blanca». ${ }^{86}$ Aunque la blanca ${ }^{87}$ era un

\footnotetext{
${ }^{85}$ Quevedo, Sueños y Discursos, 1993, vol. 2, p. 1255.

${ }^{86}$ La indeterminación del número de monedas permite introducir la alusión a las blancas y proponerlas como nexo fusionador de las dos figuras, Judas y el Judío errante, pues al primero le pagaron con treinta la entrega de Cristo y el Judío errante siempre disponía de cinco blancas en su bolsa para su sustento.

${ }^{87}$ Las cinco blancas son un elemento potenciado por la tradición española que vierte la leyenda del Judío errante en la figura de Juan Espera en Dios, pues, según recoge Bataillon (1964, p. 87), fueron «aparentemente ignoradas fuera de España hasta el siglo XIX». Por ejemplo, en la versión protestante de la leyenda, Ashaverus no tiene las cinco monedas. Se plantea entonces la cuestión de cuál era el estado de difusión de la leyenda del Judío errante en la España del XVII, a fin de analizar qué elementos de la leyenda asume Luis Martín en la «Sátira». Juan de Espera en Dios o Juan Devoto a Dios es el nombre con el que, en el siglo XVI, se designó en España al discípulo inmortal de Cristo que espera en la tierra el retorno de su maestro y al que siempre acompañan la bolsa milagrosa y las cinco monedas. A la leyenda protoevangélica de este personaje se suma en el XVII la historia de Juan Botadios o Giovanni Buttadio, el zapatero que insultó a Cristo en el camino al Calvario. Según Bataillon, este personaje fue difundido en Italia y España por los falsos peregrinos
} 
La prédica del divertimento: la figuración carnavalesca de Judas Iscariote en una sátira...

tipo de moneda, y bien podría usarse con ese sentido genérico, el empleo de tal lexema arrastra, sin duda, la evocación del Judío errante o, más bien, a su descendiente español, Juan de Espera en Dios. ${ }^{88}$

Los puntos de contacto entre las dos figuras posibilitaban fácilmente la conciliación de ambas en un texto con finalidad de crítica antisemita. Aunque Crosby encuentre en las botas y en el andar errático elementos producidos desde la propia figura de Judas, la «blanca» del v. 72 hace más factible la idea de una buscada permeabilidad entre las dos tradiciones. ${ }^{89}$

Retomando el hilo de análisis de las tres estrofas finales, algo más se puede añadir a esta comparación implícita de Judas con el Judío Errante: la degradación grotesca de la figura que ha regido la dinámica del retrato a lo largo de todas las quintillas anteriores se hace ahora patente al oponer la necedad de Judas a la omnisciencia del otro.

La quintilla siguiente, la dieciséis, esgrime dos nuevos argumentos contra los judíos:

$$
\begin{aligned}
& \text { Porque es necedad pensar } \\
& \text { que la civil sinagoga } \\
& \text { de cuartos lo ha de colmar, } \\
& \text { porque no os dará una soga } \\
& \text { cuando os queráis ahorcar. }
\end{aligned}
$$

El oxímoron «civil sinagoga» acentúa la falta de religiosidad de un pueblo como el judío, a la vez que subraya la avaricia en el hecho hipotético de de negarle los judíos a Judas hasta la soga con que este pudiera ahorcarse. Lo que se impone en esta parte final de la «Sátira» es una extensión analógica de los rasgos

\footnotetext{
que se hacían pasar por los insultadores de Cristo y utilizaban la argucia del engaño para conseguir fácilmente dinero. Así pues, en el XVII la leyenda del zapatero de Jerusalén o Judío errante queda vinculada a la de Juan Espera en Dios. Por tanto, en estos estadios germinales de la leyenda del Judío errante en España la atribución a Judas de las entronca con la imagen de este personaje de Juan de Espera en Dios, mezcla del folclore español y de la leyenda del Judío errante.

${ }^{88}$ Así lo entiende Quevedo en los versos tres y cuatro del romance Significa su amor a una dama y procura introducir la doctrina del no dar a las mujeres: «que por faltarme las blancas / no soy Juan de Espera en Dios» (Quevedo, Poesía original completa, 1999, núm. 710, p. 803).

${ }^{89}$ Los dos personajes, Judas y el Judío errante, se presentaban juntos como figuras que acompañaban los pasos de Semana Santa. Así ocurren en Puente Genil, donde en la procesión de Nuestro Señor de la Humildad y la Paciencia «sin guardar con respecto a los pasos y la marcha un orden preciso, aparece ya el Judío errante, al que en las procesiones siguientes también suele vérsele aquí o allá» (Caro Baroja, 1988, p. 69). Tanto Judas como el Judío errante se transformaban por unas horas en bufones, siendo objeto de las burlas y mofas de los devotos procesionarios.
} 
negativos con que se ha caracterizado a Judas en las quintillas que anteceden al conjunto del pueblo judío. Así ocurre con la avaricia, que articula el ridículo retrato de Judas - significada en el tópico de la venta de Cristo por poco dinero y la bolsa constituida en símbolo de esa misma codicia - , hiperbolizada en los versos: «poque no os dará una soga / cuando os queráis ahorcar».

El chiste con el que concluye la penúltima quintilla — «qqué le han de dar a un vil / que le abolló la mollera / al padre con un astil?» (vv. 83-85) redunda, de nuevo, en la condición pérfida del pueblo judío.

La estrofa dieciocho cierra la sátira finalizando la red metafórica de asociaciones organizada en torno al juego:

\author{
Quiero dejaros, cuitado; \\ que debéis de estar corrido \\ por la vaya que os he dado, \\ pues, como quien ha perdido, \\ hacéis cara de ahorcado
}

En el juego con los «sisones despenseros» ${ }^{90}$ Judas ha perdido y, como en el juego del ahorcado, la cuerda es el castigo (vv. 89-90). Las asociaciones

\footnotetext{
${ }^{90}$ La relación entre los despenseros y Judas ya la había establecido Quevedo en su prosa (Martín Fernández, 1979, p. 133). El adjetivo de «sisón» aplicado a despensero está en el Sueño del Infierno. Y en el del Juicio aparece "sisón» atribuido a Judas, patrón infernal de los despenseros, además de la explicación pseudoetimológica de la atribución del adjetivo «sisón» a los despenseros, mediante un divertido juego de palabras: «[...]dijo vn demonio: Despenseros son; y otros: No son; y otros: Sì son. Dioles tanta pesadumbre la palabra sison que se turbaron mucho» (Quevedo, Sueños y Discursos, 1993, vol. 1, p. 135). Los despenseros eran los que se encargaban de surtir la despensa de sus amos, pero ya en el Libro del buen Amor señaló el Arcipreste de Hita el dinero que le robaban a éstos. A causa de los hurtos desmedidos, se les tachó de ladrones en la literatura satírica del XVI. Como tal aparecen en el Guzmán de Alfarache y en el Buscón. El engaño y la traición del despensero hacia su amo así como el hecho de llevar en las bolsas el dinero y las compras son puntos de enlace entre la figura de Judas y tales despenseros. Crosby señala como lugar coincidente en Luis Martín de la Plaza y Quevedo la equiparación de despensero y ladrón a través del adjetivo «sisón», trasladando las connotaciones negativas de tales despenseros al apóstol: «Y siendo el despensero sisón, como dicen Quevedo y Luis Martín, será «ladrón» [...] para los dos autores, Judas era ladrón que llevaba bolsón». (Quevedo, Sueños y Discursos, 1993, vol. 2, p. 990). En su obra poética también son numerosos los ejemplos en que Quevedo equipara a Judas con los despenseros. Reproducimos los más significativos. Por ejemplo, sobre el verso «este fue despensero y sacerdote» (Quevedo, Poesía original completa, 1999, núm. 875, p. 1227, vv. 169-172) anotan L. Schwartz e I. Arellano que Judas «aparece en los textos satíricos como patrón de los despenseros» (Quevedo, Un Heráclito cristiano, Canta sola a Lisi y otros poemas, 1998, p. 325). Podemos añadir a éste «de discípulo, a ingrato despensero» (Quevedo, Poesía original completa, 1999, núm. 172, pp. 163-4, v. 7), cambio de actitud del apóstol al que Luis Martín también acude en los versos 24-25: «por interés os trocáis / de apóstol
} 
La prédica del divertimento: la figuración carnavalesca de Judas Iscariote en una sátira...

metafóricas han constituido un tejido asociativo cuyas relaciones se hacen más complejas a medida que introduce nuevos elementos en el contexto figurado ya establecido. Además, también «perdido» (v. 89) pone en funcionamiento el equívoco a través de la dilogía, extendiendo, así, la red metafórica del juego que empezó con «picado y fullero» (v. 31), seguía con «habéis jugado con sisones despenseros» (v. 41), y acababa en «que aun en todo no tenéis / para un juego del rentoy» ${ }^{91}$ (vv. 64-65). «Perder» tiene aquí el sentido recto, pero lo que Judas acaba perdiendo, más allá del dinero, será su propia vida - «hacéis cara de ahorcado» (v. 90) - y, en una transposición más, la propia salvación, pues está condenado a vagar eternamente como las figuras de Juan Espera en Dios o el Judío errante. No es el Judas traidor, ni el avaro, la figura que Luis Martín instituye desde las palabras de su «Sátira a Judas Iscariote», sino la triste imagen del perdedor, del burlado.

\section{Una nueva figuración de Judas}

El tratamiento de la traición del apóstol diverge en enfoque de los discursos anteriores sobre el apóstol. Luis Martín ofrece en la «Sátira» la imagen de un perdedor, a través de la figuración bufonesca del personaje, potencializando la escenificación y dramatización. Elige, para ello, el momento inmediatamente posterior a la finalización de la Cena con el propósito de situar la figura en el abismo entre la ambición y el remordimiento, en ese territorio lábil que revela la propia contradicción de la naturaleza humana.

\footnotetext{
en belleguín»). Por último, citemos dos casos más: «No habrán en Madrid despensero / a Judas más obligado» (Quevedo, Poesía original completa, 1999, núm. 674, p. 701, vv. 21-22); y «Y yo, que en diez y seis años / que tengo de despensero, / aún no he podido ser Judas, / y vender a mi maestro» (Quevedo, Poesía original completa, 1999, núm. 697, p. 678, vv. 129-132).

Si activamos, desde la invectiva a los judíos de estas últimas estrofas, la dimensión de crítica social, la denominación de «despenseros» alcanza al propio Judas - aunque en Luis Martín no es tan explícita como en Quevedo - y a los que hacen tratos con él, los judíos. Queda implícito, pues, que en la Hacienda española los judíos, encargados de administrarla, son, igualmente, «sisones despenseros». ${ }_{91}$ 'Juego de naipes, que se juega de compañeros entre dos, quatro, seis, y a veces entre ocho personas. Se dan tres cartas a cada uno, y después se descubre la inmediata, la qual queda por muestra, y según el palo sale son los triunfos aquella mano. La malilla es el dos de todos los palos y esta es la que gana a todas las demás cartas; solo cuando es convenio de los que juegan, que ponen por superior a el cuatro, a el que llaman borrego, y la malilla se queda en segundo lugar después del rey, caballo, sota, as, y así va siguiendo el siete y las demás hasta el tres que es la más inferior. Se juegan bazas como al hombre y se envida como al truque, haciéndose señas los compañeros'. (Diccionario de Autoridades).
} 
De ahí que la última estrofa recupere la primera persona enunciativa: «quiero dejaros» $\mathrm{y}$ «os he dado». La apelación al «tú», en la forma «cuitado», vuelve a fluctuar, de nuevo, en ese sistema de ambigüedades, a la condescendencia que, en otras ocasiones, mostraba el sujeto poético hacia la imagen que se ha ido conformando en el devenir de la «Sátira». En esas expansiones anfibológicas de la actitud de la voz enunciativa, la estrofa final es el último punto de inflexión.

La calificación del discurso como «vaya ${ }^{92}$ (v. 88) implica, además de la nota metapoética, la ubicación clara de la «Sátira» en un tipo de discurso muy determinado: los vejámenes a Judas. Paralelamente, suscribe su estimación como discurso oral - «pero ya mi lengua calla» (v. 15) -, establece su determinación genérica como disertación burlesca ofensiva, y, finalmente, se constituye en el elemento angular del sentido de la invectiva a partir de la dinámica condescendencia-rechazo de la voz enunciativa o productora del discurso hacia el receptor a que se apela. Si bien el esquema retórico de los textos de vejámenes a Judas es el principio organizativo y estructural de la «Sátira», Luis Martín introduce nuevos elementos que singularizan la composición. Téngase en cuenta que la literatura de vejamen florece durante el siglo XVII y todos los ejemplos que hemos podido documentar, impresos y manuscritos, son posteriores a la «Sátira» de Luis Martín, por lo que hay que situar este texto al inicio de la cadena de desarrollo de este tipo de discursos. El título de

\footnotetext{
${ }^{92}$ Quevedo emplea esta palabra en el Sueño del Infierno para designar la burla que los que caminaban por el camino izquierdo, el del vicio, hacían de los que recorrían el camino de la Virtud: «Yuamos dando vaya a los que veìamos por el camino de la Virtud màs travajados; haziamos burla de ellos, llamauamoslos hezes del mundo y desecho de la tierra» (Quevedo, Sueños y Discursos, 1993, vol. 1, p. 161). Y un poco más adelante: «Algunos [...]; otros [...] persuadidos de las razones y corridos de las vayas, cayan y se bajauan» (Quevedo, Sueños y Discursos, 1993, vol. 2, p. 1162). Crosby, en la nota a este fragmento, propone el significado de dar vaya como «burlarse, mofarse» y recoge los autores principales que han usado esta expresión: Arcipreste de Hita en el Libro del buen Amor; en 1602 es usado por Mateo Luján en Segunda parte de ... Guzmán; también en el Buscón, en Covarrubias, Correas y La pícara Justina (Quevedo, Sueños y Discursos, 1993, vol. 2, p 1143). Son de corte picaresco todas estas obras recogidas por el estudioso de Quevedo, de lo que se desprende la inclusión de la «Sátira» - que ya atestiguaban otros elementos léxicos - en ese universo marginal o del hampa. Ovando Santarén (Ocios de Castalia en diversos poemas, 1987, p. 216) en el romance compuesto para un certamen de ambientación eclesiástica usa igualmente este sustantivo cuando menciona el asunto del certamen: «Romance compuesto en un certamen que, en fiesta del Santísimo Sacramento, se celebró en la ciudad de Úbeda, de cuyos asuntos fue el uno dar vaya a Judas en veinte y cuatro coplas». En estas composiciones, junto a las de vejamen ya analizadas, lo términos de «vaya», «burla», «sátira» comparten el mismo sentido de invectiva personal.
} 
La prédica del divertimento: la figuración carnavalesca de Judas Iscariote en una sátira...

la composición, «sátira», ${ }^{93}$ como hemos visto se perpetúa en muchos de los vejámenes a Judas y se equipara a la denominación de «vaya», término con el que la voz enunciativa sumariza y «valora» su propio discurso, y ambas se instituyen en la dicotomía definidora del sentido último de la composición.

No subyace en este texto de Luis Martín una reflexión teológica profunda ni un pensamiento religioso sistemáticamente articulado. Los juegos metafóricos, las dilogías, los equívocos, van dibujando la silueta de una figura de Judas que Luis Martín reinventa en 1603 y que ahora hemos añadidos esa cadena de tratamiento literario, pictórico, artístico en general, del apóstol Iscariote. El propósito final a que apunta el discurso burlesco no tiene una determinación única. La dimensión social, cuyos aspectos hemos ido espigando, se hace presente por medio de esa actualización de la figura del apóstol en una ambientación propia del inframundo áureo. Prima la finalidad risible de la burla, la que provoca el «poner en escena» de manera «teatral» una silueta irrisoria que mueva a la carcajada. Ahora bien, nada existe tampoco de propósito subversivo en la «carnavalización» de la figura de Judas, puesto que la risa se halla plenamente integrada en el sistema humanista como simple divertimento, haya prédica o no subyacente en la invectiva antimsemita. En el caso de los vejámenes, se trata de textos enmarcados en un ámbito eclesiástico, regidos, en su génesis, por el carácter circunstancial, y cuya finalidad no es otra que la del esparcimiento de la comunidad religiosa. Luis Martín, clérigo, pero además poeta, proyecta su conciencia creadora en la génesis del texto. De ello resulta un producto artística y literariamente más logrado, que sigue las pautas de un discurso, en principio, circunstancial y sin mayores pretensiones artísticoliterarias, probablemente compuesto para los momentos de solaz de miembros de la comunidad eclesiástica, el entretenimiento en unas fiestas religiosas de Semana Santa, o la candidatura a un certamen con el mismo motivo.

\footnotetext{
${ }^{93}$ El término «sátira», como es obvio, no tenía en estos textos, ni en tros muchos del Siglo de Oro el sentido a que hoy lo asociamos en el ámbito filológico. Cacho Casal (2004, p. 61) ofrece cuatro significados asociados a la palabra «sátira» en los Siglos de Oro: «drama satírico griego, sátira menipea, sátira latina en verso y composición injuriosa». Probablemente, es éste último el sentido que tiene en el texto de Luis Martín. Ha perdido el valor de crítica social y corrección de las costumbres a favor del mero insulto. Frente a la sátira de tipo culto circulaban, normalmente manuscritos, otro tipo de textos más circunstanciales de tema político, religioso o de invectiva personal que se basaba en el carácter mordaz y ofensivo. Aquí se situaría la «Sátira a Judas Iscariote» de Luis Martín.
} 
Los núcleos de originalidad de Luis Martín respecto a los textos de vejamen a Judas - cuyo esquema acabará codificándose en discursos meramente formularios - y a otras composiciones en la que el apóstol Iscariote es figura central proceden de distintos niveles de análisis. En primer lugar, no recoge Luis Martín sólo los atributos y rasgos que tradicionalmente han caracterizado al apóstol (la bolsa o la venta por poco dinero) sino que introduce el motivo de las botas y la permeabilidad con una figura como la del Judío errante. En cuanto a la finalidad de la invectiva, aleja su discurso del simple ataque a la figura de Judas y crea un espacio de ambigüedad en el que el lector participa activamente. La figuración carnavalesca del personaje y la relevancia de la «dramatización» renuevan el universo discursivo creado por Luis Martín. Y, por último, la crítica antijudaica que origina un movimiento de apertura desde la particularización en la figura de Judas a la generalización de la prédica antisemita.

Por qué un texto como la «Sátira», enclavada en el ámbito discursivo del vejamen, fue impreso a la altura de 1603 y, además, en una antología como la Flores de poetas ilustres de Espinosa se constituye en un interrogante de problemática respuesta. Como hemos visto, la mayoría de textos de vejámenes a Judas se conservan, incluso aún hoy, manuscritos, y los que se imprimieron fue en fecha posterior a la «Sátira», principalmente desde mediados del siglo XVII. A la luz del análisis y de las conclusiones que éste ha puesto de relieve volvemos a plantearnos el sentido de la inclusión de la «Sátira a Judas a Judas Iscariote» en las Flores de poetas ilustres como antología de vanguardia y el lugar que ocupa en la secuenciación textual de las composiciones. La novedad que la composición de Luis Martín pudiera suponer en torno a 1603 estriba básicamente en razones de índole temática: es interesante la relectura que propone el antequerano de la figura de Judas como personaje bufonesco. Pero la técnica empleada se mantiene dentro de los límites del manierismo, y alejada del conceptismo sacro, por ejemplo, de Quevedo. Y en cuanto al aspecto formal, el empleo de la quintilla es escaso a principios de siglo pero acabará imponiéndose en los textos de vejámemes y burlescos desde la práctica quevediana.

La inclusión de esta composición de Luis Martín en las Flores podría responder al propósito de variedad y de novedad del antólogo. Variedad temática, estructural y formal y novedad al introducir un tipo de texto que hallará amplio cultivo a lo largo del XVII, los vejámenes a Judas. 
La prédica del divertimento: la figuración carnavalesca de Judas Iscariote en una sátira...

Esta variedad hay que considerarla también respecto a la microserie de que la «Sátira» forma parte. Las conclusiones derivadas del análisis de la «Sátira» nos permiten reubicarla en las seriaciones de las Flores de Espinosa propuesta por Belén Molina, pues, lógicamente, el análisis particularizado de cada texto ofrece nuevas pautas sobre las series en que podamos estructurarlos. Belén Molina integra la «Sátira a Judas Iscariote» en una serie que va de las composiciones 119-151, en que se insertan textos «que, en su variedad, siguen el hilo moralizante de la condena del pecado, centrado sobre todo en la codicia y ambición humanas». ${ }^{94}$ La variedad que ofrece la «Sátira» en esta serie hay que analizarla en relación a las demás composiciones, especialmente respecto de la redondilla de Quevedo «Aquí yace Monsén Diego». La «Sátira a Judas Iscariote» de Luis Martín, más que sumarse a esa condena de la avaricia y codicia humanas por medio de de la figura de Judas, se acerca a la crítica contra los judíos de la redondilla quevediana cuyo protagonismo queda puesto de relieve en las últimas quintillas. Pero, también, frente a la seriedad de la invectiva antisemita de Quevedo, el texto de Luis Martín opone el divertimento que se recrea en lo ridículo. Y más allá, el cometido del texto de Luis Martín es el de servir a esa «variedad» de que gustaba Espinosa para su antología, una diversidad que puede considerarse desde distintos planos. Primero, el de hacer convivir un sistema poético en decadencia con uno nuevo que se irá imponiendo a lo largo de la centuria: la poética manierista en un texto marcado en su génesis por la circunstancialidad (Luis Martín) con el conceptismo barroco (Quevedo y la redondilla «Aquí yace Monsén Diego). Segundo, contribuir a la diversificación estrófica: las quintillas de Luis Martín y la redondilla de Quevedo, por ejemplo, acogiendo la antología un metro cuyo cultivo iba a quedar circunscrito, a lo largo del XVII, a las composicones de burlas, entre ellas los vejámenes. Y, por último, ofrecer pluralidad en el tratamiento de un mismo tema, la crítica contra los judíos: Luis Martín opta por la figuración carnavalesca de Judas y la redondilla quevediana se recrea en la invectiva antisemita.

Hemos intentado poner de relieve en estas páginas los artificios y recursos de la prédica y el divertimento así como las posibles razones e implicaciones de su uso en un texto que acoge tanto «los argumentos de impeccabilitas» como los «de humanitas».

\footnotetext{
${ }^{94}$ Molina Huete, 2003, p. 342.
} 


\section{BibLIOGRAFÍA}

Alatorre, Antonio, «Notas filológicas en torno a Luis Martín de la Plaza», Nueva Revista de Filología Española, XLV, 2, 1997, pp. 429-445.

ASENSIO, Eugenio, "Algunas modalidades del retrato en Quevedo», en Itinerario del entremés. Desde Lope de Rueda a Quiñones de Benavente, Madrid, Gredos, 1971, 2. ${ }^{\text {a }}$ ed. revis., pp. 178-198.

Ávila, Tomás de, Epinicio sagrado..., Salamanca, 1687, 2-10720 BNM.

BAtAillon, Marcel, «Peregrinaciones españolas del Judío errante», en Varia lección de clásicos españoles, Madrid, Gredos, 1964, pp. 81-132.

CACHO CASAL, Rodrigo, La poesía burlesca de Quevedo y sus modelos italianos, Universidade de Santiago de Compostela, 2003.

---------, «La sátira en el Siglo de Oro: notas sobre un concepto controvertido», Neophilologus, 88, 2004, pp. 51-72.

CANTERO JiméNEZ, José, Plavsibles elogios, célebre octava, circulo festivo, corona que labraron, laureola que entretexieron, y victimas que sacrificaron, Sagradamente ambiciosos, En Aras de su piadoso çelo, los deuotos hijos del nunca bastantemente venerado San Felipe Neri. En sv Congregacion y nvevo Oratorio de la Nobilissima Ciudad del Valle de Vlid. A los veynte de Octubre de 1658, Madrid, 1611, G-11155, British Museum.

CARA, Giovanni, Il «vejamen» in Spagna: juicio y regocijo letterario nella prima metà del XVII saecolo, Roma, Bulzoni, 2001.

CARo BAROjA, Julio, Estudios sobre la vida tradicional española, Barcelona, Península, 1988.

CArreira, Antonio, «Luis Martín de la Plaza, o el manierismo en Antequera», Analecta Malacitana, XX, 1, 1997, págs. 291-306.

[Cancionero Antequerano] I Variedad de sonetos, ed. José Lara Garrido, Clásicos Malagueños, Cancioneros del Siglo de Oro, Diputación Provincial de Málaga, 1988.

Cancionero Antequerano recogido por los años de 1627 y 1628 por Ignacio de Toledo y Godoy, ed. Dámaso Alonso, Madrid, CSIC, Instituto Miguel de Cervantes, 1950.

Clarke, Dorothy Clotelle, «Sobre la quintilla», Revista de Filología Española, XX, 1933, pp. 28-295.

Covarrubias Orozco, Sebastián de, Tesoro de la lengua Castellana o española, Madrid, Castalia, 1994.

Etienvre, Jean Pierre, «Primores de lo jocoserio», Bulletin Hispanique, junio 2004, 1, pp. 235-252.

EsPINOSA, Pedro, Flores de poetas ilustres, RAE, 1991.

GLASER, Edward, «Referencias antisemitas en la literatura peninsular de la Edad de Oro», Nueva Revista de Filología Hispánica, VIII, 1954, pp. 39-62.

LARA GARRIDO, José, «Código temático y representación: la sátira "A una mujer flaca” de Luis Martín de la Plaza desde sus interferencias contextuales y cotextuales, o ascendencia y descendencia de una "figura" quevediana», Revista de Estudios Antequeranos, 2, 1995, pp. 414-453. 
La prédica del divertimento: la figuración carnavalesca de Judas Iscariote en una sátira...

Ledesma, Alonso de, Conceptos espirituales, 1602, R-985 BNM.

Ledesma, Alonso de, Tercera parte de Conceptos Espirituales. Con las obras hechas a la Beatificación del glorioso Patriarca Ignacio de Loyola, fundador de la Compañía de Iesus, para el Colegio de la ciudad de Segouia, 1612, R-16027 BNM.

LiDA, Raimundo, "Dos "Sueños" y un prólogo", en Prosas de Quevedo, Barcelona, Crítica, 1980, pp. 183-219.

MARTín FernánDEZ, M. ${ }^{a}$ Isabel, «Referencias judaicas en la poesía satírica de Quevedo», Anuario de Estudios Filológicos, 1979, II, Universidad de Extremadura, pp. 121-146.

Martín de la Plaza, Luis, Poesías completas, ed. Jesús M. Morata Pérez, Diputación Provincial de Málaga, 1995.

Martínez De Grimaldo, José, Fundacion, y fiestas de la Congregacion de los indignos esclavos del SS. Sacramento, que esta en el religioso convento de Santa Maria Magdalena, de la orden de S. Agvstin de esta Corte. Celebradas en los primeros cinquenta años de sv edad felice. Madrid, Diego Díaz de la Carrera, 1657, 3/62584 BNM.

Mazzocchi, Giusseppe, «Lo burlesco religioso: La Canción a Cristo crucificado de Francisco de Aldana», en Tiempo de burlas. En torno a la literatura burlesca del Siglo de Oro, eds. Javier Huerta Calvo, Emilio Peral Vega, Jesús Ponce Cárdenas, Madrid, Verbum, 2001.

Molina Huete, Belén, La trama del ramillete. Construcción y sentido de las «Flores de poetas ilustres» de Pedro Espinosa, Sevilla, Fundación José Manuel Lara, 2003.

Ovando y Santarén, Juan de, Ocios de Castalia en diversos poemas, ed. Cristóbal Cuevas, Diputación Provincial de Málaga, 1987.

Pérez Lasheras, Antonio, «Fustigat mores». Hacia el concepto de la «Sátira» en el siglo XVII, Universidad de Zaragoza, 1994.

Ponce CÁRdenAs, Jesús, «Sátira y burla en la poesía de Góngora» en Góngora y la poesía culta del XVII, Madrid, Laberinto, 2001, pp. 27-37.

Quevedo, Francisco de, Poesía varia, ed. James O. Crosby, Madrid, Cátedra, 1985.

Quevedo, Francisco de, Poesía original completa, ed. José. M. Blecua, Barcelona, Planeta, 1999.

Quevedo, Francisco de, Un Heráclito cristiano, Canta sola a Lisi y otros poemas, edición y estudio preliminar de Lia Schwartz e Ignacio Arellano, Barcelona, Crítica, 1998.

Quevedo, Francisco de, Poesía selecta, edición, estudio, bibliografía y notas de Lia Schwartz e Ignacio Arellano, PPU, Barcelona, 1989.

Quevedo, Francisco de, Sueños y Discursos, ed. James. O. Crosby, Madrid, Castalia, 1993, 2 vols.

Poesias varias de grandes ingenios españoles. Recogidas por Ioseph Alfay, R-6797 BNM.

Segunda parte de las «Flores de poetas ilustres» ordenada por D. Juan Antonio Calderón, eds. José Quirós de los Ríos y Francisco Rodríguez Marín, Imprenta E. Rasco, Sevilla, 1986.

SARABIA, Antonio de, Justa literaria, certamen poético, o sagrado influxo, en la solemne, quanto deseada Canonización del Pasmo de la Caridad, el Glorioso Patriarca y Padre de Pobres San Juand e Dios, Fundador de la Religión de la Hospitalidad. Celebróse en el claustro del Convento Hospital de Nuestra Señora del Amor de Dios, y Venerable Padre Antón Martín de esta Corte, el Domingo diez de junio del Año de mil seiscientos y noventa y vno, Madrid, Bernardo de Villa-Diego, 1692, R/15239 y 7/107913 BNM. 
Schwartz Lerner, Lia, Quevedo. Discurso y representación, Anejo $\mathrm{n}^{\mathrm{o}} 1$ de Rilce, Ediciones de la Universidad de Navarra, Pamplona, 1986

Tonos a lo Diuino y a lo Humano recogidos por el Licenciado D. Gerónimo Nieto Madaleno... y escriptos por el Maestro Manuel López Palacios..., fols. 26-27, ms. de la Biblioteca Pública de Toledo, descrito por Esteve Barba, Catálogo de la Colección de manuscritos de la Biblioteca Borbón Lorenzana, Madrid, 1942, nº 391.

VILAR, Jean, «Judas según Quevedo (un tema para una biografía)» en Francisco de Quevedo, ed. Gonzalo Sobejano, Madrid, Taurus, El escritor y la crítica, 1978, pp. 106-119.

Vorágine, Santiago de la, La leyenda dorada, Madrid, Alianza, 1982, 2 vols. 